\title{
The role of industrial heritage in sustainable tourism development Case study of Mina EL-Basal district in Alexandria -Egypt
}

\author{
Noha Ibrahim Khalil ${ }^{1}$ \\ Ayman Gamal Elgohary ${ }^{2}$ \\ ${ }^{1}$ High Institute of Tourism, Hotel Management and Restoration Abukir -Alexandria, ${ }^{2}$ Faculty of \\ Archeology, South Valley University, Antiquities
}

\begin{abstract}
Industrial heritage has become a new tourist attraction and Alexandria has great potentials in this field. This paper aims to review different forms of industrial heritage in different tourist destinations. It also attempts to provide a basis for understanding, management and development of industrial heritage in tourism with a special reference to Mina EL-Basal district in Alexandria by proposing two main hypotheses; First, there are potentials of reusing industrial heritage buildings of Mina EL-Basal in tourism. And second, Re-using industrial heritage buildings of Mina EL-Basal can positively contribute to sustainable tourism development. Methodology of "case study" was used, and data was collected using semi-structured interview addressed to stakeholders. The study shows that there are potentials for re-using industrial heritage of Mina EL-Basal district in tourism industry, and more efforts should be undertaken in this direction. The research indicated to the important role the industrial heritage of Mina EL-Basal district can play in sustainable tourism development in Alexandria, and a vision for re-using of the industrial buildings of Mina EL-Basal district has been proposed.

Keywords: Industrial Heritage, Alexandria, Mina EL-Basal District, Alexandria Heritage Catalogue of 2007, Sustainable Tourism Development.
\end{abstract}

\section{Introduction}

Tourism plays a vital role by providing a new meaning to industrial sites that is an important heritage resource as the embodiment of much of Egyptian history and in Alexandria in particular. It must be interpreted in order to re-read history and transform the original function of the industrial building into a tourist attraction. Throughout the 19ths and the 20ths, Alexandria was one of the greatest ports for trade. Alexandria economy prospered due to the growing industry and trade with other ports of the Mediterranean. Consequently, the industrial heritage of Alexandria is unique and various, but it is unfortunately neglected and not documented, and it could be faded in the very near future unless an action plan is taken. It encompasses warehouses, workshops, mills, firms, lighthouses, bridges railways etc. The objective of the study is to enrich the tourist supply through a systematic presentation of cotton bourse and cotton press buildings of Mina EL-Basal district. It also provides a broad foundation of the role of industrial heritage in sustainable tourism development. Study begins with a literature review and methodology, then the results are illustrated, discussed and finally, the conclusion and recommendations are presented giving tourism managers some insights to have the opportunity to promote the industrial heritage in the circumstances of the case.

\section{Literature Review}

\section{Industrial heritage: concept, patterns, and importance in tourism}

The transformation of industrial heritage sites into tourist attractions is a great way of maximizing region's declined economy (Xie, 2006; Douet, 2012; Cristinaa, et al., 2014). Industrial heritage is concerned with "the physical evidence of former industrial activity within the contemporary environment' (Frew, 2008). Industrial heritage tourism includes visits to industrial places of great history and no longer work, or still working industry sites that has a characteristic past. It aims to offer tourists and visitors learning experiences about technical 
operations and economic and social history of the visited places (Frew, 2008; Sánchez, 2015). For the tourist destinations, industrial heritage tourism is considered a special interest type of tourism and still has not the great attention, it can make tourist product differentiated and extend the peak season of tourism (Polyxeni, et al. 2009; Abad, C., 2019).

In case of still working industrial sites, tourism can increase customer trust in products understanding the production process and previewing raw materials (Lin, 2019)

According to Falser 2001 and Edward \& Llurdés i Coit, 1996, industrial heritage is divided into the following categories:

- Productive sites Mines and quarries- coal, lead, tin, copper, stone, wood cutting, etc.

- Processing and manufacture sites factories and workshops for metal industries, textiles mills, glasswork, and pottery, factories of all kinds, chemical production, and food and drinks production (such as wind and watermills)

-Transport and communications-roads, bridges, canals and waterways, docks, railways, ports, and harbors

-Power and utilities-gas works, sites of electricity production, and water and sewage works.

- Social /cultural attractions of industrial heritage Retail establishments and labor cottages. (Edwards \& Llurdés i Coit, 1996; Falser 2001; Aref,2013).

According to United Nations educational Scientific and Cultural Organization (UNESCO), Industrial Heritage represents $5.3 \%$ of all cultural sites and $4 \%$ of all World Heritage Sites. Although, there are no declared Industrial world heritage Sites in the Arab world and Africa, there are 28 inscribed industrial heritage sites, 22 in Europe and North America region, 4 in the Latin America and Caribbean region and 2 in the Asia and Pacific region (Falser,2001).

According to the technological advances, many industries have disappeared, and many factories have also been closed. Tourism can take advantage of historic background and sense of place. Since the 1980s, many of industrial areas were transformed into tourist destinations in order to preserve the industrial past. Industrial heritage has a rare historical value because it is a record of the human life, customs memory, and identity in a certain era. Although the industrial heritage does not have the attractiveness of other types of heritage, a number of tourist destinations started to develop the relevant regions and cities. (Timothy\& Boyd, 2002 ; Xie, 2006; Aref, 2013 ; Damir,2018).

In 2009 United Nations World Tourism Organization (UNWTO) General Assembly in Astana approved the domain of industrial heritage for tourism in three main areas (UNWTO, 2011)

- -Industrial and technological monuments such as sites, moveable heritage in museums and castles.

- Living industry of all types, including agriculture and food production.

- Intangible industrial heritage such as cultural activities catalyzed by industrial development.

There are eight reasons for visiting industrial heritage sites: the interest of the site, family and friends, recreation, promotional materials, previous visits, knowledge of the site and road signs and curiosity (Chen, Kerstetter and Graefe 2001). Many destinations started to promote industrial heritage in new contexts. It has a vital role than preservation; this process is called "heritagisation" this is not only about conservation but also stimulates alternative re-use of the industrial heritage (smith 2007; Swensen and Stenbro. 2013). 
According to Edward \& Llurdés i Coit, 1996, range of industrial heritage sites are iconic and magnets for visitors. Mines of Rammelsberg and Historic Town of Goslar are German world heritage site (Fig. 1), where visitors experience four hour adventure tour and miner's meal underground (https://en.harzinfo.de/ https://www.fagus-werk.com/). Iron bridge Gorge the birthplace of the industrial revolution, UK receives over 545,000 visitors annually (Fig. 2) (Mihic and Makarun(2017b). Industrial heritage reuse in china for cultural purposes has occurred widely in three major Chinese cities Beijing, Shanghai and Chongqing. During 1990s and the first decade of the 21st century, many factories in the three cities with varied past usage have been transformed into tourism precincts, Creative class clusters and Cultural flagship such as Warehouses, plants and factories. Consequently, Beijing's reused industrial buildings attract three millions of visitors annually. (Chen, Judd and Hawken, 2016). In Italy, Hilton Molino Stucky Venice was also once one of Europe's largest flour mills since 1895(Fig. 3). In 2007, Hilton launched the site as the Hilton Molino Stucky Venice hotel With 379 elegant guestrooms, 88 Executive rooms and 45 suites (tripadvisor; MIHIĆ and MAKARUN 2017 a).

There are also industrial museums which demonstrate products and operations like South Wales Miners Museum (Fig. 4), it was officially opened in 1976 and receives about 100,000 visitors yearly (Timothy\& Boyd 2002, diggingupthepast.org.uk). ASTRA museum in Sibiu, Romania receives about 600,000 tourists in 2017 with a growth rate 31 percent in the number of visitors yearly and 35\% of them are from foreign countries (https://business-review.eu/; Stefan,2017).

In Egypt, the adaptive reuse of industrial remains for tourism purposes is still not in tourism management concern. According to National Organization for Urban Harmony (NOUH), a comprehensive database has been prepared of the significant architectural values in all governorates in Egypt and set the necessary rules for preservation according to the license of Technical Secretariat of the Standing Committee of the Heritage Conservation Commission in Alexandria (Nassar, 2016; NOUH, 2017). According to the mentioned concept of industrial heritage the following table is summarizing industrial heritage buildings in Alexandria adapted from the Alexandria heritage catalogue 2007 Governorate.

Table 1: Documented industrial heritage buildings in Alexandria

\begin{tabular}{|l|l|l|}
\hline Documentation no. & \multicolumn{1}{|c|}{ Name of the establishment } & \multicolumn{1}{c|}{ address } \\
\hline 2131 & Misr Sabbagh Al Bayda Rest House & Al Bayda \\
\hline 2132 & Misr Sabbagh Al Bayda Warehouses Building & Borg El Arab \\
\hline 2133 & Basily Wood \& Mosque & wardian \\
\hline 1870 & Zgheib Press / Marco- Interior Design & 90 El Farahda \\
\hline 2019 & Lighthouse montazah & Montazah \\
\hline 2134 & Sabahi Management Building & Seyouf \\
\hline 4002 & Multi Pharma Pharmaceuticals \& Chemicals & Behind 106 Lavizon Street \\
\hline 2008 & Arab Petroleum Pipelines Company- Sumed & 431 El-Guish Road \\
\hline 1952 & Haj Taher Sibahi & 1 AL Ezaaa \\
\hline 1951 & Haj Taher Sibahi & 8 Al Ezaaa \\
\hline 1904 & Arab Shipping Company & 115 Ahmed Shawki \\
\hline 2103 & Carpet Factory- Ramle Fort & Borg Al Arab \\
\hline 1420 & Railway Service & Jamal Abd EL Nasser \\
\hline 224 & Egypt Maritime Transport & 10 Hassan Allam \\
\hline 603 & Al Bili wood Company (Villa Manoli( & EL Gabarty \\
\hline 124 & Don Bosco Institute & 99 ELKhedewi \\
\hline 505 & Housing workers in Kom Shuqafa rail) & EL Rahma \\
\hline 1255 & History Bridge & kabbary \\
\hline
\end{tabular}




\begin{tabular}{|l|l|l|}
\hline Documentation no. & \multicolumn{1}{|c|}{ Name of the establishment } & \multicolumn{1}{c|}{ address } \\
\hline 1706 & Stani barn Company offices & 141 EL Max \\
\hline 1711 & Arsenal Company Buildings & Western port \\
\hline 535 & Cotton Bourse Mina ELBasal & Abdel Aal Helmy Escarides \\
\hline
\end{tabular}

Source: Prepared by the researchers, Adapted from Alexandria Heritage Catalogue of 2007.

In addition, the mentioned sites in the table are only the documented ones as heritage buildings but there are many other sites some of them are registered as archeological sites such as Mandara wind Mill and El Nabih cistern, and others are old buildings with a great history such as Chimney and building of Alexandria Water Company, warehouses,lighthouses and The abundant garage of the Royal Pullman of the late king Farouk outside of Montazah palace and ther are not registered as a listed building according to law no. 144/ 2006 of protecting architectural heritage (Aref,Y,2013).

\section{Industrial heritage and sustainable tourism development}

According to World Commission on Environment and Development, "Sustainable development is development which meets the needs of the present without compromising the ability of future generations to meet their own needs" (Abi Ghanem, 2014). Industrial heritage is an important part of cultural heritage, which in turn is the major component of the sustainable development of any destination (Polyxeni and Spyridon, 2007). Industrial heritage has social, spatial, cultural, and technological past that make it complex in the matter of sustainable tourism development. The conservation and adaptive re-use of industrial heritage whose their original function run out should consider environmental, economic, and social aspects and encourage sustainable tourism development (Ifko,2016; Nassar,2016; Stefan, 2017). It could be implemented through preserving local heritage, providing job opportunities and give young generation to get involved in cultural innovation through creative tourism participative learning activities with social fabric innovative and dynamic sustainable based on local people and local resources (Richards, Wisansing and Paschinger ,2019).

The interrelationship among heritage assets, human resources and planning could be the vehicle for a sustainable tourism development (Amarilla \& conti,2012).

Adaptive reuse of Industrial heritage sites and buildings has a vital role in affirming sustainable development by reducing negative environmental impacts, job creation, micro enterprises and maximization of socio-cultural values and economic prosperity and quality of life of local community. Moreover, sustainability requires preserving local distinctiveness, and attracting visitors and new business, social solidarity, and environmental quality (Fouad, Sharaf Eldin and Mansour 2014; Stefan, 2017). Development of industrial heritage tourism is a means of both preservation and realizing economic benefits by reusing the building in a sustainable manner (Xie, 2015). In the context, Industrial heritage could be managed in one of two ways; either by preparing some sites for tourist visit or improving the conditions of the other open sites, for example, the project of the transformation of The Taiwanese plants to industrial tourism sites through the provision of tourist facilities (Timothy and Boyd, 2002; Lin, 2019).

Industrial heritage attracts visitors in Norway In Larvik, Drammen and Oslo, and the redevelopment processes were driver for urban economic growth in five projects according to the national policy (Swensen and Stenbro2013). The Zollverein coal mine industrial complex is located in Land Nordrhein-Westfalen, Germany, and it was 150 year historical coal-mining; and some $20^{\text {th }}$ century buildings, in this case re-use supported sustainability, contributed to urban development and stimulated community life (Oevermann, 2018). The Zollverein industrial complex was declared as a world heritage site since 2001; it is an architectural masterpiece of mining, created by the visionaries Fritz Schupp and Martin Kremmer (Fig. 5). 1.5 million visitors 
from all over the world are attracted yearly to the site during (2011-2017) as members in 30 guided tours with eight languages for many age groups, or visitors in exhibitions and museums and participators in festivals or relaxing in the Zollverein Park (whc.UNESCO.org ; Stiftung Zollverein.de,2018) .Essen became an interesting destination, and consequently there are increase in employment, promotion of creativity through different forms of modern art then greater revenues in the region (Copic et al., 2014). Revitalization of the old train road Mocănița in Romania was a vehicle for sustainable tourism development by providing Cultural programs and Job opportunities (Stefan, 2017). The Darjeeling Himalayan Railway, India, attracts tourists in various train journeys with reserved tickets and it is a great example of transportation built through difficult terrain, which had great influence on the social and economic development of their respective regions(Fig. 6) (whc.UNESCO.org).

Above, sustainable tourism development requires commitment to strategies of local authorities with all stakeholders and international organizations in some cases. (Colavitti and Usa, 2014). The Center for Industrial Heritage (CIB) was established in 2013 as a part of the University of Rijeka, Croatia, that implements programs and conducts activities in the field of cultural heritage (CIB, 2020; UNIRI.hr). The center also investigates the potential exploitation and reuse of industrial heritage for tourism purposes and connecting with international partners. UNWTO also sponsors the international conferences on industrial heritage and tourism, held in Zabrze (Poland) every year since 2004. Some of these conferences have been held in collaboration with the European Economic and Social Committee, the Council of Europe, UNESCO, the Polish National Committee, TICCIH (The International Committee for the Conservation of the Industrial Heritage) and ERIH (European Route For Industrial Heritage). The sixteenth ERIH Annual Conference was scheduled to take place from 7-9 October 2020 at ERIH Anchor Point Museum of Industry, Ghent, Belgium. Since 2005 ERIH organizes annual conferences, discusses a contemporary topic about industrial heritage tourism (ERIH.com).

From other side, Information communication technologies (ICTs) contribute in enhancing exhibition, visualization, and interpretation of industrial heritage, improving tourists' experience and allowing for the sustainable development of resources and the integration of visitors with the architectural, environmental, and socioeconomic environment. The Almadén mercury mining district is a good example, the webpage and digital display of content make the industrial heritage sustainable and accessible by giving tourists the opportunity of interaction, rating and giving the opinions, virtual tours, online booking, online interesting tourist attractions and multilingual information accessibility with users, and external references (Abad,2019; parqueminerodealmaden.es).

\section{Cotton trade and history of Mina ELBasal District}

Al- Mahmudiya Canal helped to revive the city of Alexandria after it reached a state of stagnation before the era of Muhammad Ali. so that it can be said that the real growth of the city took place after the year $1820 \mathrm{AD}$, the date of completion of digging Al-Mahmudiya Canal. Consequently, Alexandria regained its old commercial position as an outlet for Egyptian trade through Al-Mahmudiya Canal, the main artery for transportation between Alexandria and the rest of Egypt, this also led to the emergence of new urban districts, like Mina Al-Basal in Western

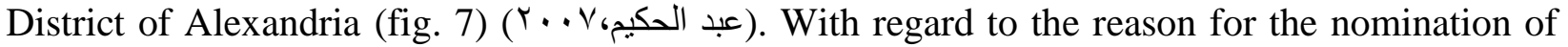
the district of Mina EL-Basal, a researcher mentioned that the name of" onion port", which was given to this region, was borrowed from its importance in exporting onions to abroad for many years, as it was among the crops popular in the export at the time( $\left.r_{\cdots} \cdot \varepsilon_{6}\right)$. However, The researchers did not find any historical texts clarifying the status of Mina al-Basal during the 
period of Muhammad Ali's rule, Ali Mubarak indicates that Muhammad Ali renewed several barns to store the grain crops without specifying their location, that were most likely located in an area adjacent to the port and Al-Mahmudiya Canal. As stated by Ali Mubarak, The urban history of the region started with the reign of Abbas I. He divided the space lands in the area of Mina El-Basal between the people of the city in which he built warehouses to receive goods in preparation for export, and given the importance of the region, its streets were tiled with a hard stone that was imported from the Italian city of Trieste during the era of Khedive Ismail ( مبارك، r.. A). This area was inhabited by residents since $1850 \mathrm{AD}$, on both sides of Al-Mahmudiya Canal, near its estuary, and around the Qabbari station. It joined the residents of the Qabbari Masjid and Shrine area, and in the late 19th century, it started to join the Manshiyya and Gomrok areas also. Transportation has facilitated its operations Transferring migrants from the countryside and Upper Egypt to Alexandria, where they lived permanently near their work in the operations of shipping and freight forwarding. Above, the inauguration of the railway and the

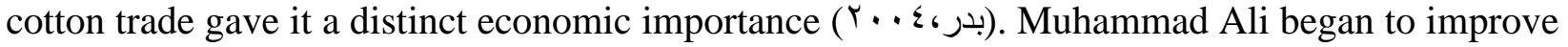
the country's resources. He used the help of the French experts, so they helped him to develop the agriculture, the most important of which is cotton cultivation (190r البهنيمي). He also exported many cotton shipments to England directly from the port of Alexandria in years of 1821-1224 AD. In 1823 AD, Egyptian cotton proved its worth in the global bourse and the Lancashire markets in England as the finest cotton in the world, where it came second after the Cotton Island. Muhammad Ali used to take over the country's cotton crop, keeping the quantity his factories needed, and the rest selling to foreign merchants, or exporting it himself to foreign

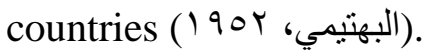

The cotton demand increased since the mid-19th century as a result of the increased demand for it in Europe, so the country's exports increased significantly by the year 1910 AD. The first sixties of the 19th century AD was the period in which cotton production prevailed over other crops to compensate for the deficit in Europe of cotton due to the American Civil War (1861$1865 \mathrm{AD}$ ) and the export of American cotton stopped, threatening European spinning mills. With the end of the war, the flow of American cotton returned again to Europe, and the demand for Egyptian cotton gradually decreased and its prices declined in the following years and the country into a temporary economic crisis. Although, the Egyptian cotton market quickly recovered in the 1970s and its exports increased year after year. After Egypt came under the British occupation, the British were keen to direct economic policy to expand cotton cultivation beyond the barrier of five million kantars by the year of 1910 AD ( $($. 11 (عباس).

Cotton presses in Alexandria:

In order to be easily shipped and exported, Cotton needs to be pressed. So that Muhammad Ali bought presses from England of the same type used in America, which was world famous in

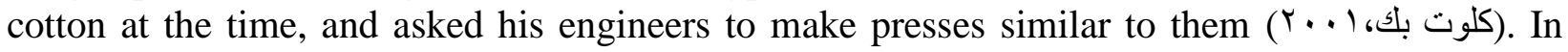
addition to these presses, Alexandria had other presses, some of which were working for the English spinning factories, as foreign merchants pressed the cotton there again( البهتيمي، 190 (ا9). For example, the Monsieur "Lenciola" owned a cotton press near Al-Asakil in Alexandria and Al-Mahmoudiya Customs, and his proximity to the sea caused fears of being exploited in the smuggling of goods without customs, so it was canceled, and the Monsieur "Tod" established a cotton press next to the windmills of Al-Mahmudiya in the direction of The Qabari railway. Ministry of foreign affairs and the Consul of England exchanged correspondence in order to transfer the press to the Mina ELbasal, but Monsieur Tod rejected because he thought that is an excessive cost to the merchants, but the order was issued on September 5, 1852AD to transfer the 
press to the Mina EL-Basal and Al-Asakil (ب. (الصعيدي،9). In the era of Khedive Ismail, cotton cultivation and industry flourished and steam-powered gins spread, which led to the activation of cotton press operations to support Egyptian cotton exports. In 1863, the Alexandria Customs

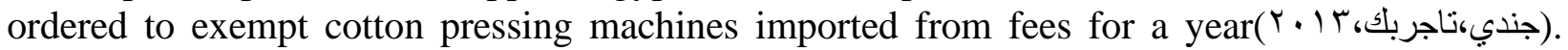
Generally, the proximity of Mina El-Basal to Alexandria port was the main reason that cotton press industry was concentrated in the region; in order to prepare Egyptian cotton for export (عبد r...人، الحكيم). In 1875 AD, Ioannis Choremis founded the Alexandria Cotton Pressing Company, and in 1889, Zervoudachis founded another company called Société General de Pressage et de Depots in order to acquire the former company, in a partnership with some British financiers who eventually took control of the company. In 1897 AD, a third cotton pressing company called Société Anonyme de Presses Libres Egyptienne was founded. It was founded by Emmanuel Benaki with the participation of a number of Greek figures. This company lasted until the fifties, which included nationalization decisions (Glavanis, 1989). Alexandria Presses" company was established on February 15, 1925, with a capital of 100,000 EGP from 25,000 stocks, the value of each one is 4 pounds (Fig. 8). However, most of its founders are foreigners, among them are major owners in Egypt, Musa Sursock (3000 stocks). The company works by pressing cotton, cleaning cotton and all the operations attached to this industry (19v0، الدسوقي). Mina El-Basal district still maintains some cotton presses that date back to the era of the Muhammad Ali family, including EL Tareekh press and the Nile press, both of which overlook the banks of AlMahmoudiya Canal, in addition to Masr press, where researchers believe that these three presses date back to the late 13th century AH / 19AD CE, specifically in 1889 AD, where the two frontiers of Tareekh press and the Nile press facing the two banks of the canal still have the remains of the original company name above the two interfaces registered in the French language (Société General de Pressage et de Depots) which is the company that was established in the year $1889 \mathrm{AD}$ as before (Fig. 9). As for the Egypt press it seems that it also goes back to the same period for the similarity of the architectural style and the style of building and Planning with the two previous presses.

El Tareekh press is located on Al-Huwais Street, and the building was licensed to the Egyptian Company for cotton pressing in 1954 and its area is 43920 square meters (Fig.10). It is a rectangular area occupied by a building block and halls vary in size between rectangular and square. Each press consists of a ground floor and two upper floors, four parallel boilers and one chimney. There were 4 cotton pressing machines in both pistons, while EL Tareekh has three only because the fourth was sold. The machines are distributed in two halls separated by a large rectangular hall in Nile press and a small square one in ELTareekh press. The facades of the two presses are divided into vertical sections and red bricks with some square windows, some are horizontal and others are vertical built in. Nile press has an area of 46800 square meters and is located at 3 Old Bridge Street with a license in 1935. It is U-shaped embraces in its arms a rectangular block surrounded by an open corridor, and this block is connected to the building surrounding it by closed metal corridors. (Fig. 11)

Masr press is located in the old Bridge Street on a public license 0f 1936. It is a rectangular area with an area of 22780 square meters. It is connected to Nile press through a covered metal corridor. There are two parallel halls in the northwestern side separated with a rectangular hall in, the right one is rectangular and includes a single pressing machine, and the left hall is square and includes two pressing machine. (Fig. 12)

In addition, Mina EL-Basal cotton bourse was built by the Italian architect Petrufuscany in 1289 $\mathrm{AH} / 1872 \mathrm{CE}$, according to the new Italian Renaissance style and was affiliated to the Sunni 
Department (Fig.13) ( $\boldsymbol{Y} \cdots \Sigma_{6}$ ). It specialized in speculating on ready-made cotton at the time of contracting immediately, so it was named after the current stock exchange and was supervised by the government in 1935. It remained under the presidency of foreigners until it took over the presidency of Mohamed Ahmed Farghaly Pasha (King of Cotton) was the first Egyptian to take over the presidency of Mina El-Basal cotton bourse and the stock market was canceled after the 1952 revolution, where Law No. 39 of 1967 was issued Three presses were established in the region related to three companies: The Egypt Cotton stock company, the Egypt Cotton Export Company, and Alexandria press company ( $Y$. . عبد الباسط، حمدي،

The building of cotton bourse is like the planning to commercial agencies, as it consists of an entrance that leads to a rectangular open courtyard overlooking the agency's buildings. And the bourse is a rectangular building consisting of two floors, ground and upper, each of which occupies rooms and halls that have doors that open on a covered corridor, which in turn overlooks an open courtyard through a row of openings, where the ground floor overlooks a row of openings held in a semicircular contract held on the shoulders Built, while the upper floor overlooks the courtyard through large rectangular openings separated by shoulders built. Also linked between the two floors are an upward ladder, and the boarding is made by a spiral staircase. The cotton bourse also overlooks the surrounding streets through three facades divided into vertical sections by shoulders. Each section includes windows, in addition to some doors.

\section{Justifications for choosing Mina EL-Basal and cotton press buildings for the field study}

Four buildings were chosen for the study, namely Mina El-Basal cotton bourse, ELTareekh Press, Masr Press, and Nile Press in the district of Mina EL-Basal. The district and the buildings were chosen due to the following considerations:

A- The historical and social importance: the four buildings are located inside Mina El-Basal district, which has a great economic history in Egypt, and is in one of the areas of outstanding value; the sixth region 6a- the western port (NOUH, 2017). The buildings were and can be partner in the daily life of Alexandrians, and may benefit the local population, and give the value of the identity of the Alexandrian people. The population in the district is 259.491 people. The district of Mina EL-Basal also includes eight kindergarten, primary, and secondary schools. (Alexandria Governorate, 2019).

B-The economic importance: The 3 presses are affiliated to the Egyptian company for Cotton Pressing, which was established by Republican Decree No. 1106 of 1965, where four cotton press companies were nationalized and are currently subject to the General Business Sector Companies Law No. 203 of 1991. According to an interview with the Industrial safety manager, The Company is renting parts of the three presses for various commercial and storage purposes in order to generate income as a result of the stopping of work in the presses buildings between 2005-2007, which gives the opportunity for reusing them again for the purposes of tourist visits. The work has been also stopped in the building of Mina EL-Basal cotton bourse and it is included in Alexandria Heritage Catalogue of 2007, code No. 535, and now contains offices for 6 cotton exporting companies and the Central Administration for Cotton Arbitration Experts. It indicates the possibility of reuse it again for various tourist visits (see fig. $13 \mathrm{c}$ )

C-Scientific importance: It refers to the information value that the industrial buildings offer to interest people from various aspects, such as architectural, historical, archaeological or artistic fields.

D- The changing causes: 
Because there is no fair system for compensation (Nassar,D,2016), There was an initiative for reusing the cotton press buildings and the cotton bourse by the Faculty of Engineering- Alexandria University to present a project funded by the French Agency for Development (AFD) for the Alexandria Governorate Within the framework of the urban plan for Alexandria for the 2032 horizon (inta- avion.org; Nassar and Sharaf Eldin,2013) (Fig. 14). During the first stage, a partnership agreement was signed between the Library of Alexandria and the French Development Agency in April 2013 on the topic of sustainable cities. This partnership, in cooperation with the Center of Mediterranean Integration (CMI), allowed the classification of four priority areas for the urban strategy of Alexandria; the rehabilitation of urban areas, the revitalization of urban areas, highlighting the value of unexploited urban areas and the institutional framework, and the Mina El-Basal project- Kafr Ashry, was included within List of urban project financing initiative projects. This was before the start of Al-Mahmoudiya Canal development project and the matter is still under implementation under the supervision of North Military District (UPFI, General Department of Urban Planning (Fig. 15). Rehabilitation is a policy where there is no historic building should be demolished until great efforts should be done (Abdelhamid, and Elfakharany, 2018). According to an interview with the chief of engineering management and supervisor of cotton pressing and storage in Jan 2020, there is also a recent project submitted and partially funded by the Egyptian Company for Cotton Pressing to the Faculty of Engineering, Alexandria University in 2019 to develop the cotton press buildings architecturally. This project was prepared after the inspection visit of the Minister of Public Business Sector for the presses on July 2019 and his recommendation that they should be preserved as heritage buildings to achieve the optimal economic return within the framework of the state's plan to develop Al- Mahmudiyah hub.

- The environmental problems as a result of the exhaust gases emitted from inside the three presses, along with the high price of the used diesel, which led to stopping work in the presses and transferring the entire cotton pressing activity to the presses of the company located in the Qabbari area.

Table 2: selected industrial heritage buildings for the re-use in tourism

\begin{tabular}{|c|c|c|c|c|c|}
\hline Building & space & $\begin{array}{c}\text { Address and date of } \\
\text { establishment }\end{array}$ & ownership & $\begin{array}{c}\text { Current } \\
\text { usage }\end{array}$ & $\begin{array}{c}\text { Suggested Assets } \\
\text { management and fund }\end{array}$ \\
\hline Nile press & $\begin{array}{l}46800 \\
\mathrm{~m} 2\end{array}$ & $\begin{array}{l}\text { It is located at } 3 \text { Old } \\
\text { Bridge Street with a } \\
\text { license in } 1935 \text {. }\end{array}$ & $\begin{array}{l}\text { Egyptian Company } \\
\text { for Pressing Cotton }\end{array}$ & $\begin{array}{l}\text { Partially } \\
\text { Rented for } \\
\text { trade purpose }\end{array}$ & \multirow{3}{*}{$\begin{array}{c}\text { Revenue sharing policy } \\
\text { among( North Military District } \\
\text {-ministry of tourism and } \\
\text { antiquities - Alexandria } \\
\text { governorate and private } \\
\text { investors }\end{array}$} \\
\hline $\begin{array}{l}\text { El Tareekh } \\
\text { press }\end{array}$ & $\begin{array}{l}43920 \\
\mathrm{~m} 2\end{array}$ & $\begin{array}{l}\text { It is located on Al- } \\
\text { Huwais Street, and the } \\
\text { building was licensed } \\
\text { to the Egyptian } \\
\text { Company for cotton } \\
\text { pressing in } 1954 \text {. }\end{array}$ & $\begin{array}{l}\text { Egyptian Company } \\
\text { for Pressing Cotton }\end{array}$ & $\begin{array}{l}\text { Partially } \\
\text { Rented for } \\
\text { storage }\end{array}$ & \\
\hline Masr press & $\begin{array}{l}22780 \\
\mathrm{~m} 2\end{array}$ & $\begin{array}{l}\text { is located in the old } \\
\text { Bridge Street on a } \\
\text { public license of } 1936\end{array}$ & $\begin{array}{l}\text { Egyptian Company } \\
\text { for Pressing Cotton }\end{array}$ & $\begin{array}{l}\text { Partially } \\
\text { Rented } \\
\text { storage } \\
\end{array}$ & \\
\hline $\begin{array}{l}\text { Cotton } \\
\text { bourse }\end{array}$ & $\begin{array}{l}14600 \\
\mathrm{~m} 2\end{array}$ & $\begin{array}{l}\text { Was established in } \\
1872 \text { by the Italian } \\
\text { engineer Petro } \\
\text { Avoscanio and was } \\
\text { affiliated to the Sunni } \\
\text { Department. }\end{array}$ & Ministry of finance & $\begin{array}{ll}\text { Rent } & \text { for } \\
\text { storage } & \end{array}$ & $\begin{array}{l}\text { Revenue sharing policy among } \\
\text { (Alexandria governorate- } \\
\text { North Military District } \\
\text {-ministry of tourism and } \\
\text { antiquities and private } \\
\text { investor) }\end{array}$ \\
\hline
\end{tabular}

Source: Adapted by the researchers from literature, interviews and documents from Egyptian Company for Cotton Pressing and General Department of Urban Planning, Alexandria Governorate. 
According to previous justifications, the documents of The General Department of Urban Planning, researches about Mina EL-Basal district and interviews with stakeholders, SWOT analysis for the reusing of industrial heritage buildings in Mina EL-Basal is proposed as follows.

Table.3: SWOT analysis for the reusing of industrial heritage buildings in Mina EL-Basal

\begin{tabular}{|c|c|}
\hline Strengths & Weaknesses \\
\hline $\begin{array}{l}\text { - Good status of the closed industrial buildings. } \\
\text { - Buildings' Historical background. } \\
\text { - Including cotton bourse building in Alexandria Heritage } \\
\text { Catalogue of } 2007 \\
\text { - Stakeholders' belief that tourism can contribute to the } \\
\text { development of the Mina El-Basal region. } \\
\text { - Accessibility of buildings to Alexandria port and Borg El } \\
\text { Arab airport, heritage tourist sites and city center. }\end{array}$ & $\begin{array}{l}\text { - Low level of safety. } \\
\text { - Low level of infra-structure. } \\
\text { - High density of wastes. } \\
\text { - Traffic congestion. } \\
\text { - Lack of coordination between stakeholders. }\end{array}$ \\
\hline Opportunities & Threats \\
\hline $\begin{array}{l}\text { - Development initiatives of the industrial buildings in the } \\
\text { district. } \\
\text { - } 2030 \text { vision of the government. } \\
\text { - Development of Al-Mahmoudiya hub (sherian el Amal). }\end{array}$ & $\begin{array}{l}\text { - Not including presses buildings Alexandria } \\
\text { Heritage Catalogue of } 2007 \\
\text { - An inadequate legislative framework. } \\
\text { - No database of industrial heritage buildings. } \\
\text { - Ambiguity of the concept of industrial } \\
\text { heritage. } \\
\text { - High cost of re-using financing. }\end{array}$ \\
\hline
\end{tabular}

Source: The researchers.

\section{Methodology:}

The study adopted the "case study" approach using:

1- Participant observation, which is preferable to use in descriptive studies, especially those related to the elements of the societies culture, as it contributes to a more accurate analysis of the phenomenon because it includes the researchers' experience of the research community directly and closely.

2- Semi-structured interview was used by preparing a list of questions in advance, consisting of two sections; the first section: includes questions about the personal data of the sample members, while the second section relates to the industrial heritage buildings using a Likert scale of five points $(1=$ absolutely disagree, $2=$ disagree, $3=$ neutral, $4=$ agree, and $5=$ absolutely agree).

Snowball sampling was used. It is non-probability sampling method used to locate hidden populations. It depends on identifying initial subjects in the population then asks them to recommend others. It is used when the population is limited and needed to be discovered (Handcock \& Gile, 2011, Johnson, 2014). The questions were directed in the same order to thirty of stakeholders in Alexandria Governorate, the Western District of Alexandria, the Egyptian Company for Cotton Pressing, the Egyptian

General Authority for Tourism Promotion, the Egyptian Federation of Tourist chambers (Chamber of Tourism Companies), the syndicate of Tour Guides, the Regional Authority for Tourism Promotion, and the Ministry of Tourism and Antiquities. and also, a phone call was made with the project manager of the French Development Agency (AFD), a professor at the Faculty of engineering Alexandria University. The study was during the period NovemberJanuary, and each interview lasted about 15 minutes. Table 4 shows the members of the sample (stakeholders).

Table 4: Members of the snowball sample (Stakeholders)

\begin{tabular}{|l|l|l|}
\hline No. & Sample members' jobs & Organization \\
\hline 1 & Office Manager & the Egyptian General Authority for Tourism Promotion \\
\hline 1 & officer & the Egyptian General Authority for Tourism Promotion \\
\hline
\end{tabular}




\begin{tabular}{|l|l|l|}
\hline 1 & Head of office of the syndicate & the syndicate of Tour Guides \\
\hline 2 & $\begin{array}{l}\text { Tourist Guide and researcher in Alexandrian } \\
\text { heritage }\end{array}$ & the syndicate of Tour Guides \\
\hline 1 & Office Manager & Ministry of Tourism \\
\hline 1 & Office Manager & the Regional Authority for Tourism Promotion \\
\hline 1 & chairman & $\begin{array}{l}\text { the Egyptian Federation of Tourist chambers (Chamber } \\
\text { of Tourism Companies) }\end{array}$ \\
\hline 1 & Industrial safety personnel & the Egyptian Company for Cotton Pressing \\
\hline 1 & Industrial safety manager & the Egyptian Company for Cotton Pressing \\
\hline 1 & engineer & the Egyptian Company for Cotton Pressing \\
\hline 1 & Financial analyzer & the Egyptian Company for Cotton Pressing \\
\hline 1 & Legal affairs manager & the Egyptian Company for Cotton Pressing \\
\hline 1 & Industrial buildings manager & the Egyptian Company for Cotton Pressing \\
\hline 1 & $\begin{array}{l}\text { chief of engineering management and supervisor } \\
\text { of cotton pressing and storage }\end{array}$ & the Egyptian Company for Cotton Pressing \\
\hline 1 & Manager of El Tareekh press & the Egyptian Company for Cotton Pressing \\
\hline 1 & Manager of Information center & Alexandria governorate \\
\hline 1 & General secretary & Alexandria governorate \\
\hline 1 & urban planning office engineer & Alexandria governorate \\
\hline 1 & $\begin{array}{l}\text { Heritage department manager secretary of General } \\
\text { secretary }\end{array}$ & Alexandria governorate \\
\hline 1 & Secretary of Heritage committee & Alexandria governorate \\
\hline 1 & $\begin{array}{l}\text { A member of Heritage committee and general } \\
\text { manager of Islamic antiquities in Alexandria and } \\
\text { western coast }\end{array}$ & Alexandria governorate \\
\hline 1 & Manager of Economic Affairs & Alexandria governorate \\
\hline 1 & General secretary & Western District of Alexandria \\
\hline 1 & Manager of Information center & Western District of Alexandria \\
\hline 1 & urban planning officer & Western District of Alexandria \\
\hline 1 & Researcher in Alex med & Alexandria Library \\
\hline 1 & Professor of tourist guidance & Alexandria university \\
\hline 2 & Antiquities inspector & Ministry of tourism and antiquities \\
\hline & & \\
\hline
\end{tabular}

\section{Hypotheses of the study:}

H1: There are potentials of reusing industrial heritage buildings of Mina El-Basal in tourism.

H2: Re-using industrial heritage of Mina EL-Basal can positively contribute to sustainable tourism development.

\section{Findings}

The reliability coefficient was calculated using alpha-cronbach. It has reached (0.93), which indicated to the high stability and consistency of internal content of the study sample and reflected the effect on validity, which is 0.96 .

Table No. (5) illustrates Respondents' opinions on the potentials of reusing the industrial heritage buildings of Mina EL-Basal in tourism, the results indicated that mean 4.7 told that respondents see that Alexandria is an industrial city due to the many types of industries it is famous for, which indicates, in accordance with the results of the study of Cristina 2014, the possibility of distinguishing Alexandria internationally as an industrial destination. The results also indicated the necessity for workers to participate in the development and re-using buildings with mean 4.6 and they all already have expressed their approval for re-using the buildings in tourism instead of closing or demolition. Mean of 4.5 also showed that the authenticity and good status of the building are potentials of reusing heritage buildings. Mean 4.4 also indicated to the necessity of having a database for the industrial heritage sites in Alexandria, which means the need for 
documentation of industrial heritage buildings and reconsidering some of them to be included in Alexandria Heritage Catalogue in a specialized section. Respondents also believe that tourism can contribute to the development of Mina El-Basal district, where the mean 4.3 indicated to their belief in the positive economic impact of tourism in improving the quality of life. The mean 4.2 indicated to respondents' awareness of the industrial buildings of Mina El-Basal, clarifying its importance to the Alexandrians. The results indicate that respondents know that there are initiatives to develop industrial heritage buildings in Mina El-Basal region with mean of 3.5, which indicates to their awareness about the initiatives with coefficient variation of $22.19 \%$ and standard deviation of .77 . The same mean indicated that respondents believed in importance of acceptance of owners of industrial establishments to convert them into tourist attractions, but legislative framework should found a fair system for compensation (Nassar, 2016).

Vagueness of industrial heritage concept is an important obstacle for reusing of industrial heritage buildings in tourist activities where mean was 4.7 , and coefficient variation $12.32 \%$. The results indicate that respondents believe that legislation related to heritage buildings is an obstacle of the reuse of industrial heritage buildings, with mean of 4.7 and coefficient variation of $12.68 \%$. Legislations Lack the identifying of financial resources for compensation for owners of heritage buildings, in addition to the absence of any article in legislations that allow to the New Urban Communities Authority to purchase heritage buildings; add to that legislations overtaking of the relationship between owners interests and heritage conservation. Financing problems is one of the most important obstacles and this was confirmed by mean of 4.5 and coefficient variation of $13.70 \%$. Mean of 4.4 indicates that safety problems in the district is also an important obstacle for re-using of buildings for tourism purposes, with coefficient variation of $14.8 \%$, because of the existence of drug dealers in Mina EL-Basal (Abi Ghanem 2014).

Road and traffic congestion and noise are constraints of reusing industrial heritage sites and buildings with mean 4.3. It was found that the lack of coordination between stakeholders is also an obstacle to reusing industrial heritage buildings in Mina El-Basal with mean 3.9. Mean 2.1 indicates the low level of the infrastructure from the viewpoint of respondents which means that it could be considered as an obstacle of the reuse of industrial heritage in Mina EL-Basal district.

Table (5): Respondents' opinions on the potentials of reusing the industrial heritage buildings of Mina EL-

\begin{tabular}{|c|c|c|c|c|c|c|c|c|}
\hline \multicolumn{9}{|c|}{ Basal in tourism } \\
\hline & SA & $\mathbf{A}$ & $\mathbf{N}$ & D & SD & mean & S. D. & C.V \\
\hline $\begin{array}{l}\text { Alexandria could be considered an industrial } \\
\text { city }\end{array}$ & 24 & 4 & 2 & - & - & 4.7 & 0.58 & $\% 12.32$ \\
\hline $\begin{array}{l}\text { You have information about industrial } \\
\text { buildings status in Mina EL-Basal }=\text { district. }\end{array}$ & 16 & 7 & 5 & 2 & - & 4.2 & 0.97 & $\% 22.94$ \\
\hline $\begin{array}{l}\text { Infra- structure of Mina EL-- heritage district } \\
\text { is good. }\end{array}$ & 2 & - & 4 & 17 & 7 & 2.1 & 0.99 & $\% 47.37$ \\
\hline $\begin{array}{l}\text { Owners of the industrial heritage buildings } \\
\text { may approve to conversion of them partially } \\
\text { or completely to tourist visitor centers. }\end{array}$ & 5 & 9 & 14 & 2 & - & 3.5 & 0.85 & $\% 24.06$ \\
\hline $\begin{array}{l}\text { Industrial heritage buildings of Mina EL-Basal } \\
\text { should have data base. }\end{array}$ & 19 & 6 & 5 & - & - & 4.4 & 0.77 & $\% 17.37$ \\
\hline $\begin{array}{l}\text { There are previous initiatives for conversion } \\
\text { of the buildings. }\end{array}$ & 5 & 5 & 20 & - & - & 3.5 & 0.77 & $\% 22.19$ \\
\hline $\begin{array}{l}\text { The buildings are Authentic and in a good } \\
\text { status. }\end{array}$ & 19 & 9 & 2 & - & - & 4.5 & 0.62 & $\% 13.70$ \\
\hline Tourism can contribute in developing the area. & 14 & 11 & 5 & - & - & 4.3 & 0.74 & $\% 17.43$ \\
\hline $\begin{array}{l}\text { Road and traffic congestion and noise are } \\
\text { obstacles for re-using of buildings for tourism }\end{array}$ & 16 & 12 & 2 & - & - & 4.3 & 0.75 & $\% 17.44$ \\
\hline
\end{tabular}




\begin{tabular}{|c|c|c|c|c|c|c|c|c|}
\hline purposes. & & & & & & & & \\
\hline $\begin{array}{l}\text { Safety problems in the district are one of the } \\
\text { obstacles to the re-use of buildings for tourism } \\
\text { purposes. }\end{array}$ & 24 & 4 & 2 & - & - & 4.4 & 0.63 & $\% 14.08$ \\
\hline The concept of industrial heritage is not clear. & 23 & 5 & 2 & - & - & 4.7 & 0.58 & $\% 12.32$ \\
\hline $\begin{array}{l}\text { Legislation framework of heritage buildings is } \\
\text { one of the most important obstacles of } \\
\text { building reuse. }\end{array}$ & 12 & 5 & 13 & - & - & 4.7 & 0.59 & $\% 12.68$ \\
\hline $\begin{array}{l}\text { Lack of Coordination between stakeholders is } \\
\text { one of the most important obstacles to reusing } \\
\text { industrial heritage buildings. }\end{array}$ & 19 & 7 & 4 & - & - & 3.9 & 0.93 & $\% 23.39$ \\
\hline $\begin{array}{l}\text { Finance is an obstacle for reusing industrial } \\
\text { heritage. }\end{array}$ & 19 & 9 & 2 & - & - & 4.5 & 0.63 & $\% 13.70$ \\
\hline $\begin{array}{l}\text { The participation of employees is a necessity } \\
\text { for development of industrial heritage } \\
\text { buildings. }\end{array}$ & 21 & 7 & 2 & - & - & 4.6 & 0.61 & $\% 13.27$ \\
\hline
\end{tabular}

Calculated mean refers to the expected role for the reuse of industrial heritage in sustainable tourism development. Firstly, providing job opportunities with mean of 4.37 followed by mean of 4.27 for the development of the tourist influx to Alexandria, finding a new revenue source for building owners, Affirming the identity of citizens and pride of their history, providing educational activities about industries for the local people, and Greening the buildings and Protection of surrounding environment. Will Provide a creative tourist product with mean of 4.23. The results indicate that the re-use of buildings in tourism will achieve the economic, socio/cultural and environmental dimensions of sustainable tourism development (Table 6).

Table 6: Respondents' opinions of the expected role of re-using industrial heritage of Mina EL-Basal in sustainable tourism development.

\begin{tabular}{|l|c|c|c|c|c|c|c|c|} 
& $\begin{array}{c}\text { Strongly } \\
\text { agree }\end{array}$ & agree & undefined & $\begin{array}{c}\text { not } \\
\text { agree }\end{array}$ & $\begin{array}{l}\text { Strongly } \\
\text { Disagree }\end{array}$ & mean & S.D & C.V \\
\hline Job opportunities. & 16 & 9 & 5 & - & - & 4.37 & 0.76 & $\% 17.52$ \\
\hline New type of revenues for the owners. & 14 & 10 & 6 & - & - & 4.27 & 0.78 & $\% 18.40$ \\
\hline $\begin{array}{l}\text { Increasing tourist arrivals to } \\
\text { Alexandria. }\end{array}$ & 13 & 12 & 5 & - & - & 4.27 & 0.74 & $\% 17.34$ \\
\hline Pride of local people of their identity. & 13 & 12 & 5 & - & - & 4.27 & 0.74 & $\% 17.34$ \\
\hline Creative tourist product. & 13 & 11 & 6 & - & - & 4.23 & 0.77 & $\% 18.28$ \\
\hline $\begin{array}{l}\text { Providing educational activities } \\
\text { about industries for the local people. }\end{array}$ & 13 & 12 & 5 & - & - & 4.27 & 0.74 & $\% 17.34$ \\
\hline $\begin{array}{l}\text { Greening the buildings and } \\
\text { Protection surrounding } \\
\text { environment. of }\end{array}$ & 14 & 10 & 6 & - & - & 4.27 & 0.78 & $\% 18.40$ \\
\hline
\end{tabular}

One sample (T) Test was also used to demonstrate that there are potentials for the reuse of the industrial heritage in tourism those are authenticity and Good status of the buildings, participation of employees in development process, possibility of distinguishing Alexandria internationally as an industrial destination, Stakeholders belief that tourism can contribute to the development of the Mina El-Basal region, initiatives of the industrial buildings in the district. Although there are also obstacles which are the inadequate legislative framework, absence of industrial heritage documentation, Ambiguity of the concept of industrial heritage, Traffic congestion, Low level of infra-structure, Lack of coordination between stakeholders and Low level of safety. The analysis showed that P- value was 0.00 (less than level of significance $(\alpha)$ 0.05 , which strongly indicates the validity of the first hypothesis (alternative hypothesis) and confirms that there are potentials of reusing the industrial heritage buildings of Mina EL-Basal in tourism (Table 6).

Table 7: T-test for potentials of industrial heritage reuse in tourism in 


\begin{tabular}{|c|c|c|c|}
\multirow{2}{*}{ Sample size } & \multicolumn{2}{|c|}{ Mina EL- Basal district } & p-value \\
\hline 30 & mean & t-stat & 0.000 \\
\hline
\end{tabular}

The analysis showed also that the level of significance of the calculated $(\mathrm{T})$ test for the second hypothesis was 0.00 (less than 0.05), which strongly indicates that industrial heritage re-using can positively contribute to sustainable tourism development. The re-use of the buildings could lead to new types of revenues, increasing tourist arrivals to Alexandria, job opportunities, Creative tourist product, providing educational activities about industries for the local people and greening the buildings and protection of surrounding environment. (Table 8 ).

Table 8: T-test for the role of industrial heritage reuse in Mina EL- Basal district in sustainable tourism development

\begin{tabular}{|c|c|c|c|} 
Sample size & mean & t-stat & p-value \\
\hline 30 & 4.27 & 9.38 & 0.000 \\
\hline
\end{tabular}

\section{A proposed vision and suggested multi-uses for the industrial heritage buildings of Mina El-} Basal district in tourism purposes

According to UNWTO report entitled "Industrial Heritage in Tourism Policies for Sustainable Development", Industrial heritage can be used in tourism purposes, in many ways where it can become visitor attraction and consequently develop a new tourism product. Tourists can visit and enjoy collections and sights or museums and enjoy aesthetic values of architecture and artifacts and intangible industrial heritage events (UNWTO, 2011).

According to Lagerqvist (2012) all types of industrial heritage sites and buildings could be reused in tourism development in a sustainable manner as followsing:

- Narratives on previous activities and people (in a museum setting by using information and communication technologies (ICTs), industrial routes and walking tours).

- A center for transfer of knowledge and skills for specific productions or crafts (living museum and children educational city, library, etc.).

- Working place for activities that builds on the local tradition (art center, Exhibition rooms, Art museum, workshops, craft production center, events halls, Boutique hotel, art halls, etc.)

- A working place for activities where the facilities constitute valuable resources. (Cafes and restaurants, conference centers and gift shops).

Based on the above, a proposed vision and Suggested multi-uses for the industrial heritage buildings for of Mina El-Basal district in a manner that contributes to achieving sustainable tourism development is as follows in tables 9-10.

Table 9: A proposed vision for re-using of industrial heritage buildings of Mina El-Basal district in tourism purposes

\begin{tabular}{|c|c|c|}
\hline Policy & strategies & Expected outcomes \\
\hline Rehabilitation & $\begin{array}{l}\text { - Maintenance and restoration of } \\
\text { industrial buildings with preserving } \\
\text { the original status of walls, floors, } \\
\text { windows and doors with minimal } \\
\text { change according to their conditions } \\
\text { through: } \\
\text { - Proposing a contemporary usage for } \\
\text { the building while maintaining } \\
\text { historical importance of the building } \\
\text { Past use. } \\
\text { - Identifying stakeholders and all } \\
\text { interests. } \\
\text { - Identifying needs of owners. }\end{array}$ & $\begin{array}{l}\text { Sustainability of built heritage through: } \\
\text { - Economic dimension: Find new directions of } \\
\text { development. } \\
\text { - Assuring buildings' utility while preserving historic, } \\
\text { aesthetic and social importance. } \\
\text { - Socio-cultural dimension: } \\
\text { - keeping the identity and authenticity of the } \\
\text { building } \\
\text { - Integration of heritage conservation and urban } \\
\text { development. } \\
\text { - Environmental dimension: } \\
\text { Protection of surrounding environment especially after } \\
\text { the backfilling of Al- Mahmudiya Canal. }\end{array}$ \\
\hline
\end{tabular}




\begin{tabular}{|c|c|c|}
\hline & $\begin{array}{l}\text { - Providing fund. } \\
\text { - Cleaning of contaminated and neglected } \\
\text { land in former industrial areas. }\end{array}$ & \\
\hline $\begin{array}{l}\text { "Heritagisation } \\
\text { (presentation } \\
\text { of industrial } \\
\text { heritage in a } \\
\text { tourism } \\
\text { context }\end{array}$ & $\begin{array}{l}\text { - Identification of tourist market } \\
\text { (students of schools and universities, } \\
\text { heritage tourists and all visitors and } \\
\text { tourists of Alexandria). } \\
\text { - Ensuring employment of local people } \\
\text { and their involvement. } \\
\text { - Visitors services (security, gardens, } \\
\text { toilets, kids area, gift shops, etc.). } \\
\text { - creative activities. } \\
\text { - Designing Educational heritage } \\
\text { programs for all market segments. } \\
\text { - Interpretation with new technologies. } \\
\text { - Planned tourist routes and walking } \\
\text { tours. } \\
\text { - greening of industrial buildings }\end{array}$ & $\begin{array}{l}\text { Sustainable tourism development } \\
\text { Economic dimension: } \\
\text { - Revenues from ticket sales, which } \\
\text { can be considered direct source of income. The } \\
\text { indirect sources of income include sales of food, } \\
\text { beverages, travel expenses and accommodation. } \\
\text { - More visitors to the destination. } \\
\text { - New job opportunities. } \\
\text { - Socio-cultural dimension: Preserves memory of } \\
\text { the local community through Knowledge } \\
\text { transmission. } \\
\text { - Sustainability of artistry technology by promoting } \\
\text { the crafts. } \\
\text { - Identification of city's cultural image as industrial } \\
\text { destination. } \\
\text { - New product of creative tourism } \\
\text { - -authentic experience } \\
\text { - Tourist safety. } \\
\text { - Improving tourists' experience and greater } \\
\text { interaction between visitors, buildings, or sites. } \\
\text { - Integration of visitors with the architectural, } \\
\text { environmental, and socioeconomic environment. } \\
\text { - Enhancing the self-esteem of local community } \\
\text { through having knowledge of their heritage. } \\
\text { - Environmental dimension: new ecosystems in } \\
\text { buildings. }\end{array}$ \\
\hline
\end{tabular}

Source: The researchers.

Table10: Suggested tourist multi-uses for the industrial heritage buildings of Mina EL-Basal district Suggested multi-uses for the industrial heritage buildings of Mina EL-Basal district

\section{Nile press :}

- Living museum in the yards of presses and boilers and the first floor stuffed with interactive virtual reality screens displaying the history of cotton pressing and the technology of hologram displaying the labors while pressing operations. Employment would be from the old labors of the presses as local guide. Museum should have Webpage, virtual tours and access to multimedia tools like audios and videos. Visitors will be from domestic and international visitors.

- Museum garden stuffed with cafes and restaurants in the internal ground floor.

- Children educational center and library on the second floor with digital leaflets and 3D models from photographs. Employment would be from the old labors of the presses as local guide and visitors will be from students not only international and domestic visitors but also from the citizens in the district and the city of Alexandria.

- Third floor will be event hall especially for the events related to the industrial life like Labor Day, establishment of the faculties and institutes of engineering and Workers University, celebrating graduation parties, the establishment of the Ministry of Industry and Trade, the Federation of Egyptian Industries and the Chamber of Commerce celebrating (Fig. 16).

\section{El Tareekh press :}

- Internal Ground floor includes a maintenance workshop and an employee office whose design and furniture is unique, so it will be as it is for manager. The left yard should be a garden with seats for visitors. 
- First floor which was containing rooms of women who was working in pressing cotton, it will be art Exhibition halls for women artists and craft workers.

- Second floor is for pressing machines so that crafts workshops will be suitable. (Fig .17)

Masr press :

-Roof will be multi cafés and restaurants yard.

- Craft production center like Almuiz visitor center first floor for hands -on programs.

- Second floor will be conference center.

-external ground floor will be for gift shops except for the rented part. (Fig. 18)

\section{Cotton bourse :}

- Agro-industrial art museum demonstrating the history of cotton with cafes and restaurants (Fig .19)

Source: The researchers.

\section{Conclusion and Recommendations}

Although industrial heritage is not a primary or even a secondary tourist attraction to any destination by itself, the potential of the re-use of industrial heritage in tourism industry has been increased apparently as an instrument for urban restructuring and sustainable economic development. Alexandria has richness in industrial heritage, thus potential of re-using are significant. It should be indicated that this was purely an exploratory study and the results indicated that there are potentials of re-using industrial heritage buildings of Mina EL-Basal district. Many of the obstacles are expected to be eliminated within the framework of the state's plan to develop Al- Mahmudiya hub. Above, the results of the study confirmed that the expected outcomes of the proposed vision of the re-use of the industrial heritage buildings are achieving the economic, socio-cultural and environmental dimensions of sustainable tourism development by providing the creative tourism pattern in order to increase tourist influx to Alexandria and give the local community a chance to learn and be proud of their great industrial past. The study recommends documenting the three industrial buildings of presses due to the distinguished history, architecture and adding them to Alexandria Heritage Catalogue. Virtual museum of industrial heritage in Alexandria should be designated in order to documentation in collaboration with the organization of Museums with No Frontiers. The study also suggests designing a tourist map for the industrial heritage sites of Alexandria, so that cooperation in its design and promotion is carried out between International Committee for Documentation and Conservation of Buildings(TICCIH), Sites and Neighborhoods of the Modern Movement (DOCOMOMO), the Syndicate of Tour Guides in Alexandria, Alex Med and the Egyptian General Authority for Tourism Promotion for promoting innovative itineraries for one- day trips and special interest and creating diverse Industrial routes. Syndicate of Tour Guides should also provide training courses for tourist guides about that new tourist product. Many industrial sites and buildings in Alexandria as well as many towns in Egypt need to be observed and used for several adaptive purposes. It is also necessary to form a committee to accept the grievances of owners of the heritage buildings and to pay appropriate and fair compensation in order to make a fair managing system for tensions between owners and legislations in the heritage conservation. This topic still needs to be widely studied; so that future research should investigate tourist profile, reasons for visiting industrial heritage, authenticity of experience, motivations, expectations and visitors' safety in industrial heritage sites in Egypt.

Bibliography

Abad, C.J.P. (2019). Application of Digital Techniques in Industrial Heritage Areas and Building Efficient Management Models: Some Case Studies in Spain. Applied sciences,.9(20), (last accessed Feb,2020) . 
Abdelhamid, M.A, Elfakharany, M. M. (2018). Introducing the Rehabilitation Policy in Order to Safeguard the Built Heritage Case Study: Hammam El Masry in Alexandria. Resourceedings 1 (2), 124-136.

Abi Ghanem, M. (2014). Sustainable urban revitalization of postindustrial landscapes: the casestudy of Minet El Bassal In Alexandria, Egypt. a thesis submitted in partial fulfillment of the requirements for the degree of Master of Urban Design to the Department of Engineering and Architecture of the Faculty of Architecture and Graphic Design at the American University of Beirut.

Alexandria Governorate (2019) Information and Decision Support Center in Alexandria Governorate statistical reports 2019.

Almaden mining park, https://www.parqueminerodealmaden.es/museo_mercurio/index.php?idioma=in (last accessed Feb, 2020).

Aref, Y. (2013) Alexandria Forgotten Architecture Reintegration of Industrial Heritage of Alexandria in Urban Development Plans. http://www.aaha.ch/cahiers/aaha-cahier-70aref.pdf, (last accessed Nov., 2019.

Amarilla, B. and Conti, A. (2012) 'Built Heritage and Sustainable Tourism: Conceptual, Economic and Social Variables Beatriz", https://www.researchgate.net/publication/221925574_Built_Heritage_and_Sustainable_Tou rism_Conceptual_Economic_and_Social_Variables, (last accessed Nov,2019.

Chen, J.S., Kerstetter, D. and Graefe, A.(2001). Tourists' Reasons for Visiting Industrial Heritage Sites. Journal of Hospitality \& Leisure Marketing, 8(1-2), 19-31.

Chen, J, Judd, B and Hawken, S. (2016). Adaptive reuse of industrial heritage for cultural purposes in Beijing, Shanghai and Chongqing, Structural Survey. 34 (4/5), 331-350.

CIB, http://cib.uniri.hr/about-the-center/\#team (last accessed Feb,2020).

Colavitti, A. M. and Usai, A. (2014)"Partnership building strategy in place branding as a tool to improve cultural heritage district's design, The experience of UNESCO's mining heritage district in Sardinia, Italy. Journal of Cultural Heritage Management and Sustainable Development, 5(2).151-175.

Copic et.al. (2014). Transformation of Industrial Heritage - an Example of Tourism Industry Development in the Ruhr Area (Germany). Geographica Pannonica, 18, (2), 43-50.

Cristinaa, F. et al. (2014). Conversion of industrial heritage as a vector of cultural regeneration Merciu. Procedia-Social and Behavioral Sciences 122, 162 - 166.

Damir, M. (2018). Denkmal(?) Erbe(?) Perplexity: The Dilemmatic Recognition of the Gabbari Railway Station in Alexandria, Egypt. https://www.researchgate.net/publication/320986998_Denkmal_Erbe_perplexity_The_dile mmatic_recognition_of_the_Gabbari_Historical_Railway_Station_in_Alexandria_Egypt (last accessed June,2013).

Douet, J. (2012). Industrial heritage re-tooled, The TICCIH guide to Industrial Heritage Conservation", https://ticcih.org/new-book/, (last accessed Nov.,2019).

Edwards, J.A. and Llurdés i Coit , J.C. (1996). Mines and quarries: Industrial heritage tourism. Annals of Tourism Research, 23 (2), 341-363.

European Route of Industrial Heritage (ERIH), https://www.erih.net/what-is-new/erih-annualconferences/ (Last accessed Feb. 2020).

Falser, M. (2001). Is industrial heritage underrepresented on the world heritage list? Global Strategy Studies Industrial Heritage Analysis World Heritage List and Tentative List 
UNESCO World Heritage Center, https://whc.UNESCO.org/archive/ind-study01.pdf (last accessed Nov. 2019).

Frew.E.A.(2008). Industrial Tourism Theory and Implemented Strategies, Advances in Culture. Tourism and Hospitality Research,. 2, 27-42.

French Agency for Development (AFD), "Alexandria: Regenerating the city A contribution based on AFD experiences", https://intaaivn.org/images/cc/Transmed/AlexandriaContribution.pdf (last accessed Nov,2019).

Fouad, S.S., Sharaf Eldin, S. and Mansour, Y.M. (2014). The innovative reuse of post-industrial heritage in Minet El Bassal district as a strategy for preservation. $9^{\text {th }}$ International Conference on Structural Analysis of Historical Constructions F. Peña\& M. Chávez (eds.), 14-17 October 2014, http://www.hms.civil.uminho.pt/sahc/2014/topic12-fullpaper010.pdf (last accessed Feb. 2020).

Glavanis, P.M., (1989). Aspects of The Economic and Social History Of The Greek Community In Alexandria During The Nineteenth Century. Thesis Submitted For The Degree Of Doctor Of Philosophy In The University Of Hull, 1989.

Handcock,M.S \& Gile, K.J. (2011) "On the Concept of Snowball Sampling", http://arxiv.org/pdf/1108.0301.pdf (last accessed June,2013).

https://en.harzinfo.de/things-to-see-do/sights-attractions/caves-miningmuseums/detail/rammelsberg-museum-and-visitor-mine-11151.html, (last accessed Feb2020.

https://www.academia.edu/3790323/Industrial_Heritage_Tourism_as_a_Special_Interest_Touris m_Form. The case_of_the_Prefecture_of_Magnesia_in_Greece (last accessed Feb, 2020). https://www.bbc.com/news/uk-england-shropshire-28118722, (last accessed Feb,2020).

https://www.fagus-werk.com

Ifko, S. (2016). Comprehensive Management of Industrial Heritage Sites as A Basis for Sustainable Regeneration, Procedia engineering, 161, 2040-2045.

Johnson, T.P. (2014). Snowball Sampling: Introduction. https://www.researchgate.net/publication/316414208_Snowball_Sampling_Introduction (last accessed Nov. 2019).

Lagerqvist, B. (2009). The production of industrial heritage and the heritage in industrial production Working order as model for heritage practices. https://www.gu.se/digitalAssets/1334/1334377_tampere-paper---pdf-2.pdf (last accessed Nov,2019).

Lin, C.L. (2019). The analysis of sustainable development strategies for industrial tourism based on IOA-NRM approach. Journal of Cleaner Production, 241, 1-20.

Mihić, I.G. and Makarun, E. (2017 a). Policy Learning Guidelines on Industrial HeritageTourism. https://www.interregeurope.eu/fileadmin/user_upload/tx_tevprojects/library/file_15177547 14.pdf (last accessed Feb 2020).

Mihić, I.G. and Makarun, E. (2017b). State of the art in Industrial Heritage and responsible tourism work shop industrial heritage tourism 14-15 March 2017 https://www.interregeurope.eu/fileadmin/user_upload/tx_tevprojects/library/CFIH_UOR_S tate\%20of\%20the\%20art\%20in\%20IH.pdf (last accessed Nov, 2019).

Mountain Railways of India, http://whc.UNESCO.org/en/list/944 (last accessed Feb. 2020. 
National Organization for Urban Harmony (NOUH), http://www.urbanharmony.org/guide/Buildings\%20and\%20heritage\%20areas/Part\%20II.pd f (last accessed Nov, 2019).

National Organization for Urban Harmony NOUH (2017)"The boundaries and foundations of preserving areas of outstanding value In Alexandria - Alexandria Governorate.

Naasar, D. (2016). Heritage Conservation Management in Egypt The Balance between Heritage Conservation and Real-Estate Development in Alexandria. Asia-Pacific International Conference on Environment- Behavior Studies, St Leonard Hall, Edinburgh University, United Kingdom, 27-30 July 2016.

-Nassar, D.M. and Sharaf Eldin, S. (2013). A new life for the industrial heritage of Minet ElBassal at Alexandria. https://inta-aivn.org/images/cc/Transmed/NassarD_NewLife.pdf (last accessed Feb. 2020).

Oevermann, H. (2018). Good practice for industrial heritage sites: systematization, indicators, and case. Journal of Cultural Heritage Management and Sustainable Development, 10(2), 157-171.

Polyxeni, M. et al. (2009). Industrial Heritage Tourism as A Special Interest Tourism Form. The case of The Prefecture of Magnesia in Greece. 10th International World Cultural Tourism Conference 2009, 13th - 15th November 2009, Bangkok, Thailand, In Conference proceedings, pp. 479-493.

Polyxeni, M.P.S. (2007). Representations and Perceptions of Industrial Heritage in the Higher Technological Education Institute in Greece: An empirical Study. Journal of science and technology(e-JST),3(3), 33-48.

Richards, G. Wisansing, J.J. and Paschinger, E. (2019). Creating Creative Tourism Toolkit, Bangkok: Book plus Publishing,

https://perfectlink.co.th/wp-content/uploads/2019/01/Creating-Creative-Tourism-

Toolkit_Version-Eng.pdf, (last accessed Nov. 2019).

Sánchez, A.V. (2015). Heritage and Tourism: A Review of the Literature. In Waterton, E.(ed.), The Palgrave handbook of contemporary heritage research, https://link.springer.com/chapter/10.1057/9781137293565_14 (last accessed Nov. 2019).

Smith, M.K. (2007). Tourism, culture and regeneration, Oxford: Cabi Publishing.

Stefan, C. (2017). Industrial heritage- a platform for cultural routes and tourism European Union European Regional development fund,

https://www.interregeurope.eu/fileadmin/user_upload/tx_tevprojects/library/Ciprian\%20Stefan_ ASTRA\%20v2\%20RO.pdf (last accessed Nov, 2019).

Stiftung

$\mathrm{Z}$.

https://www.zollverein.de/app/uploads/2018/09/180601_Basic_Press_Release_Tourism.pdf (last accessed Feb. 2020).

Swensen, G. and Stenbro, R. (2013). Urban planning and industrial heritage - a Norwegian case study Journal of Cultural Heritage Management and Sustainable Development, 3 (2), 175190.

The South Wales Miner's museum, https://www.diggingupthepast.org.uk/swmm.html, (last accessed Feb, 2020).

https://business-review.eu/news/astra-museum-in-sibiu-over-600000-tourists-in-2017-154358,

(last accessed Feb, 2020).

Timothy, D and Boyd, S. W. (2003). Heritage tourism, New York: Pearson Education.

Tripadvisor.com.eg (last accessed Feb. 2020). 
Uniri,http://iuri.uniri.hr/center/center-for-industrial-heritage-cib/ (last accessed Feb 2020).

UNWTO (2011)"Report on the outcome of the seminar on industrial Heritage in tourism Policies For sustainable Development", https://webunwto.s3.euwest1.amazonaws.com/imported_images/27139/report_seminar_industrial_tourism_zabrze _poland_2011.pdf (last accessed Feb,2020).

Urban projects finance initiative (UPFI). Rehabilitation project for the cotton industry and its suburbs (Mina El-Basal and Kafr Ashry) in Alexandria", http://upfi-med.eib.org/ (last accessed Nov,2019).

Xie, P. F. (2015). A life cycle model of industrial heritage development", Annals of Tourism Research Vol. 55 No. pp. 141-154.

Xie, P. (2006). Developing industrial heritage tourism: A case study of the proposed jeep museum in Toledo", Ohio, https://www.sciencedirect.com/science/article/abs/pii/S0261517705000853 (last accessed Nov. 2019).

Zollverein Coal Mine Industrial Complex in Essen, https://whc.UNESCO.org/en/list/975/ (last accessed Nov, 2019).

بدر، أحمد سعيد عثان (ع . . ץ). التطور العمراني والمعماري بمدينة الإسكندرية من عهد محمد علي إلى عهد إسماعيل،

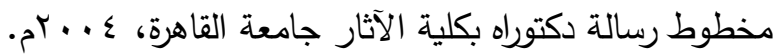

البهتيمي، مصطفى علي (90Y 1 ). تاريخ زراعة القطن في مصروأهم أصنافه، مصر .

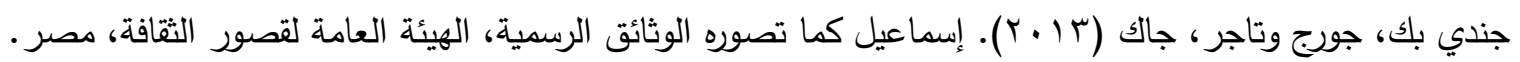

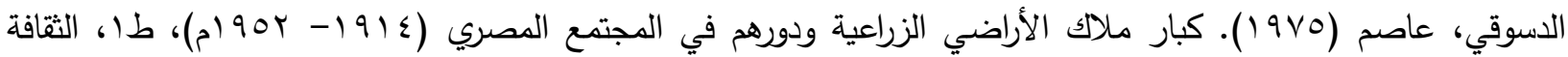

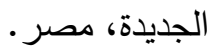

الصعيدي، إسلام محمد سيف (9 ( • ( ). ترعة المحمودية وأثرها على التطور الاقتصادي والعمراني والاجتماعي لمدينتي

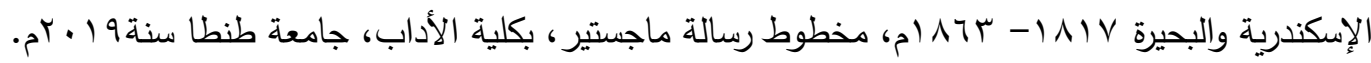

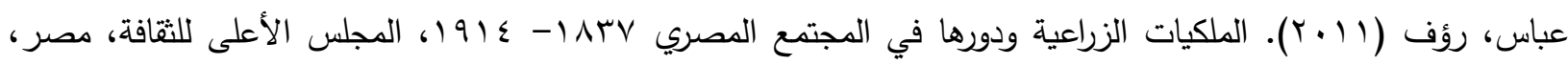
$6 r+11$

عبد الباسط، حسام، حمدي، محمد السيد، ذاكرة الإسكندرية الفوتوغرافية، الإسكندرية: مكتبة الإسكندرية. عبد الحكيم، محمد صبحي (Y. . . V). مدينة الإسكندرية، الهيئة المصرية العامة للكتاب.

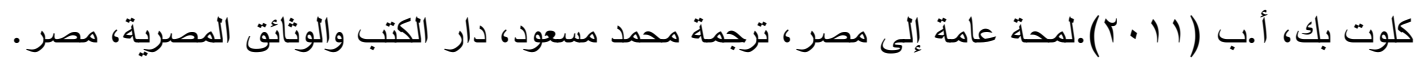
مبارك، علي (1 . . ץ). الخطط التوفيقية الجديدة لمصر والقاهرة ومدنها وبلادها القديمة والثهيرة، ج V، الهيئة المصرية للكتاب، مصر . 
Fig. (1): Mines of Rammelsberg.

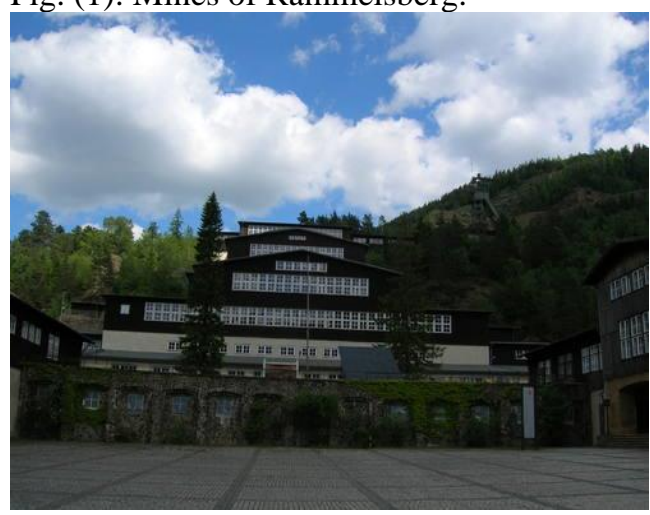

Source: UNESCO

Fig. (3): Hilton Molino Stucky Venice.

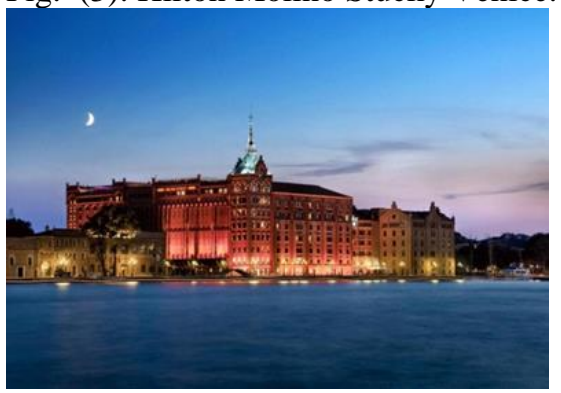

Source: Hilton website

Fig. (5): The Zollverein coal mine industrial complex.

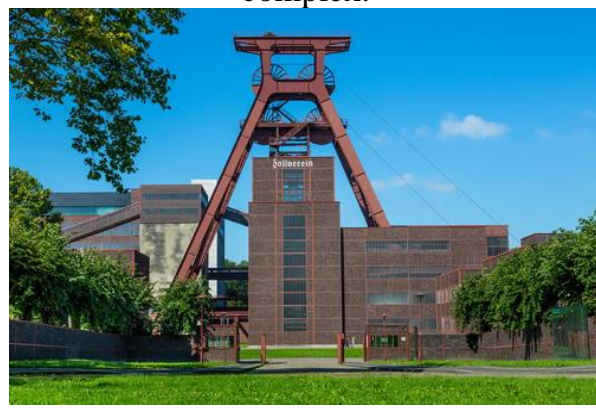

Source: UNESCO

Fig. (7a): Mina EL-Basal presses map.

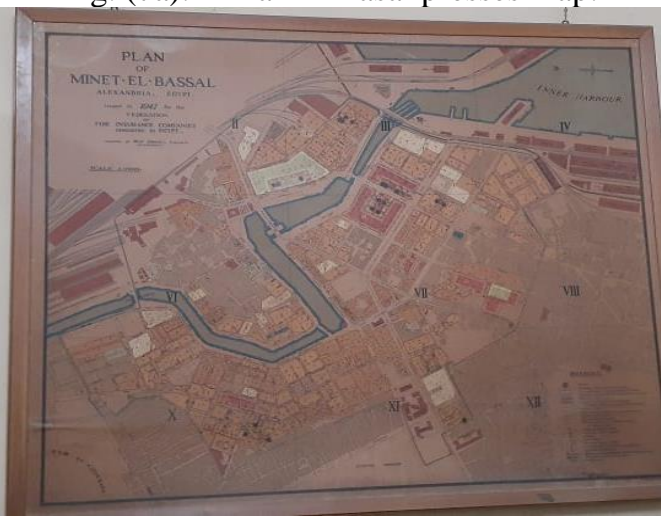

Source: Egyptian company for cotton pressing
Fig. (2): Iron Bridge Gorge.

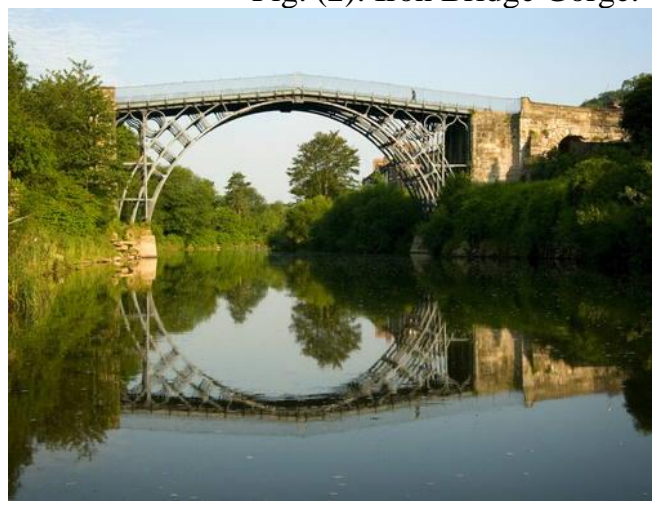

Source: UNESCO

Fig. (4): South wales miners museum.

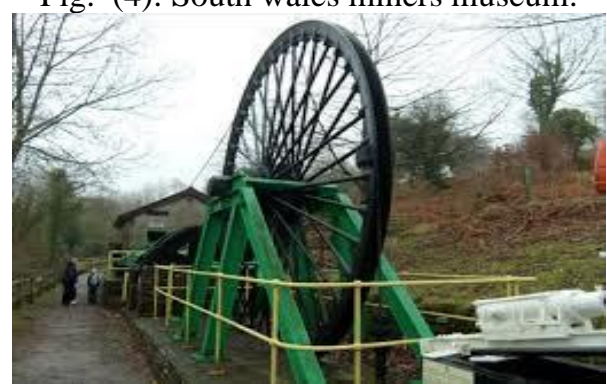

Source: diggingupthepast.org.uk

Fig. (6): Darjeeling Himalayan Railway.

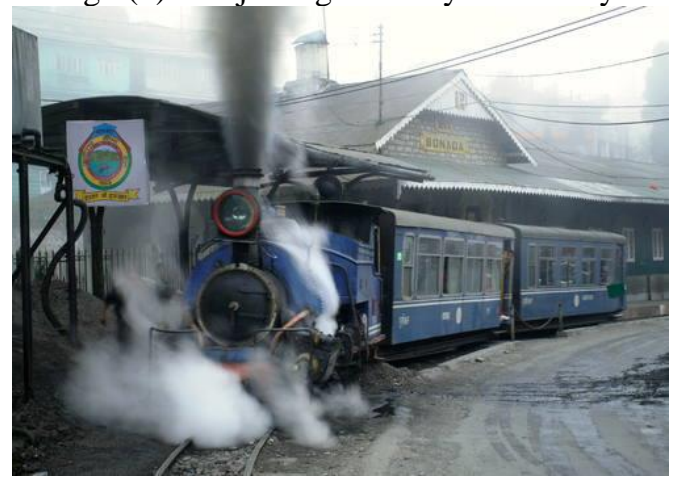

Source: UNESCO

Fig. (7b): A rare scene of Mina EL-Basal area and cotton landing in the beginning of past century.

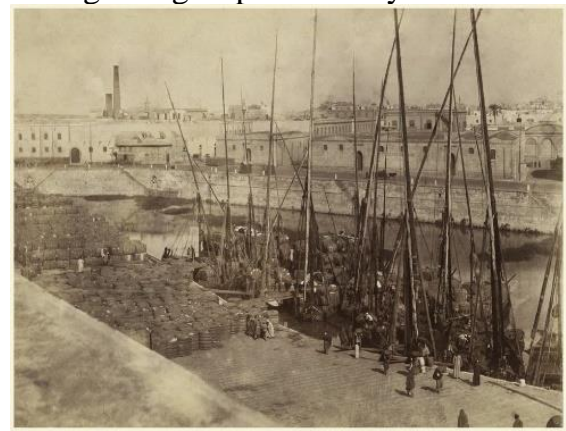

https://www.facebook.com/292536804170226/photos/a.29254 $4324169474 / 2896066637150550 /$ type $=3 \&$ theater 
Fig. (8): Two pictures of Egyptian company for cotton pressing headquarter.
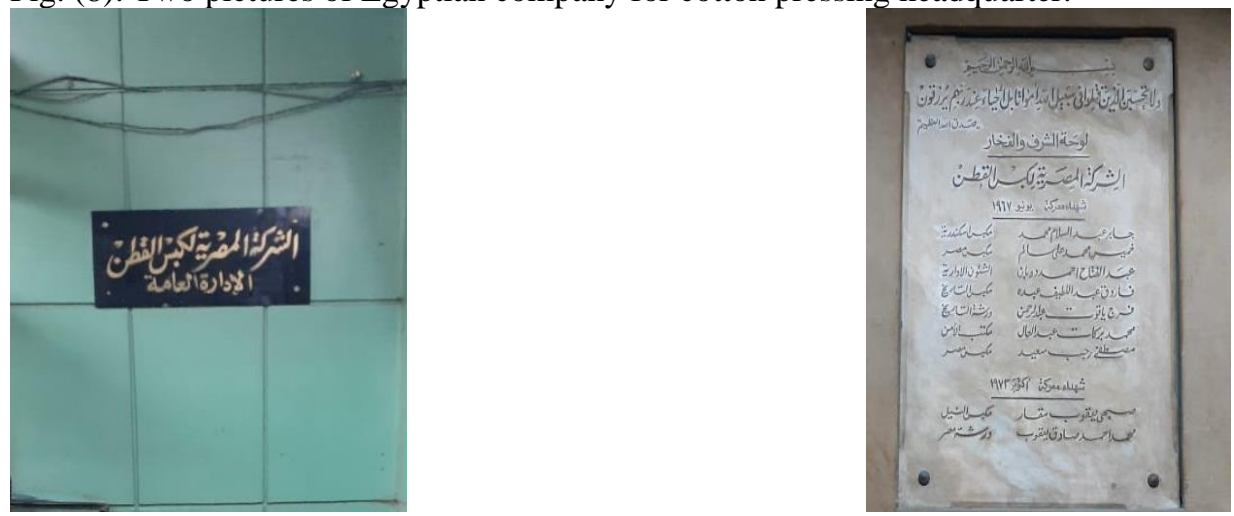

Source: The researchers

Fig. (9): Façade of Nile press.

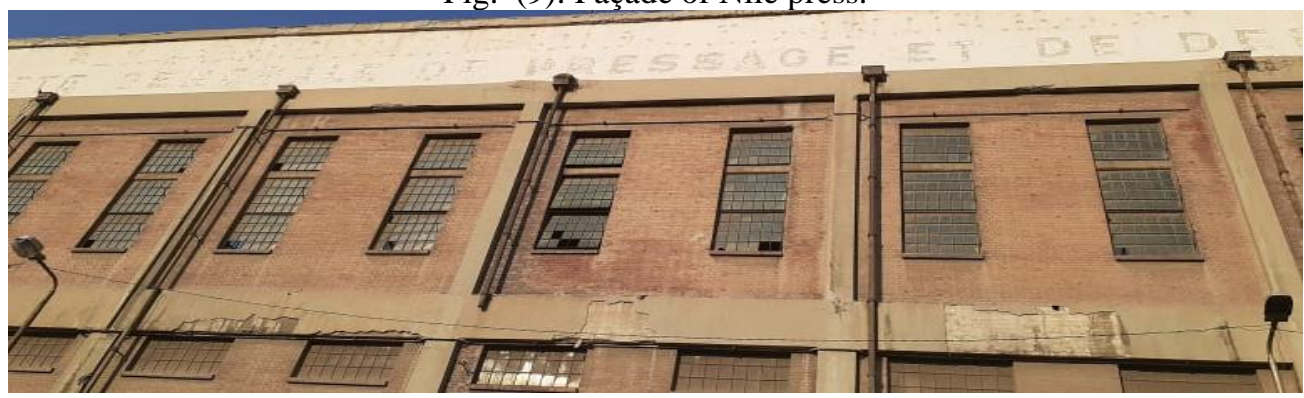

Source: The researchers

Fig. (10a): Entrance of El Tareekh press

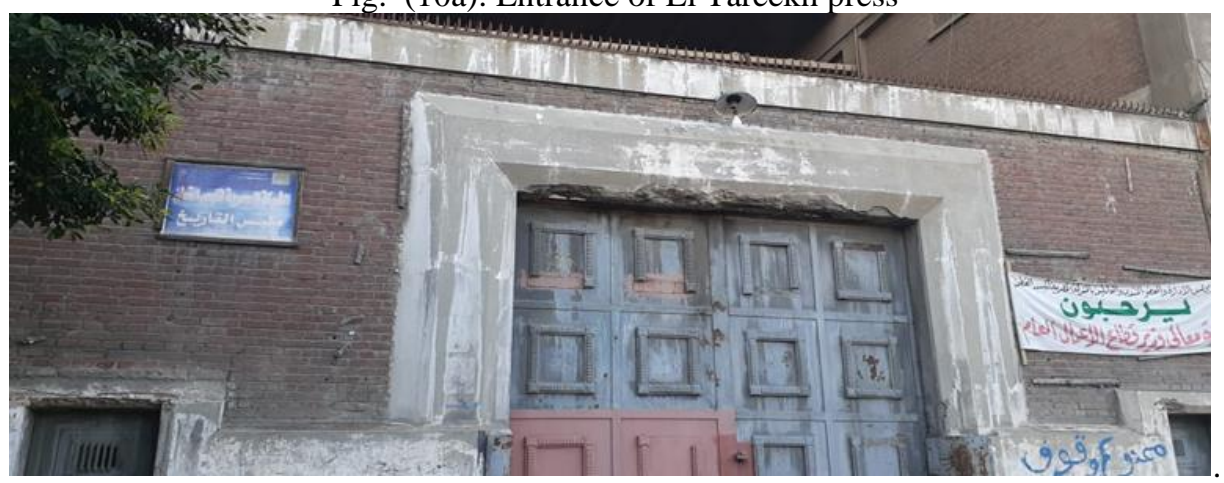

Source: The researchers

Fig. (10b): Architecture of El Tareekh press

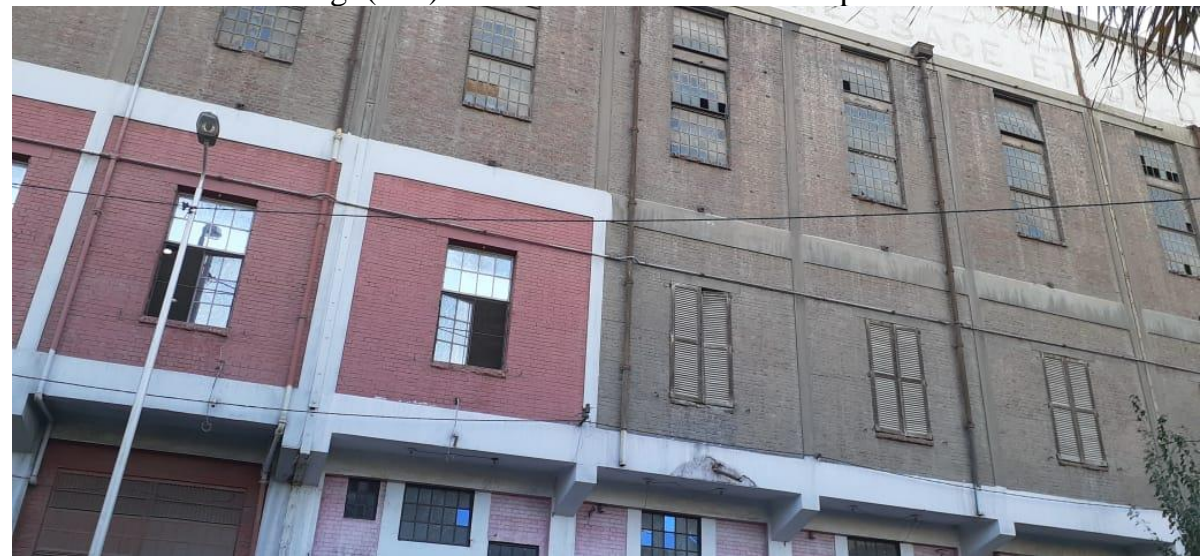

Source: The researchers 
Fig. (10c): Horizontal projection for the ground floor of El Tareekh press

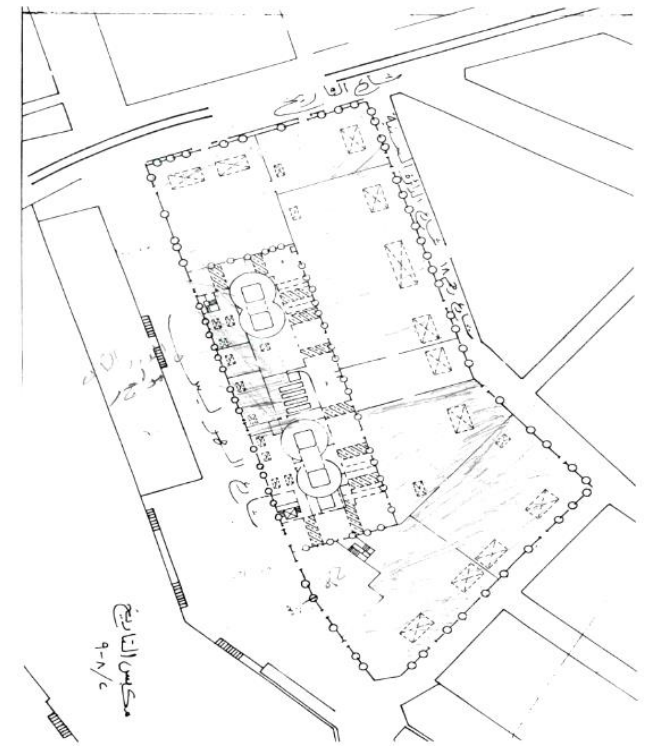

Source: Egyptian company for cotton pressing

Fig. (11a): Nile press maser press and the bridge connecting them

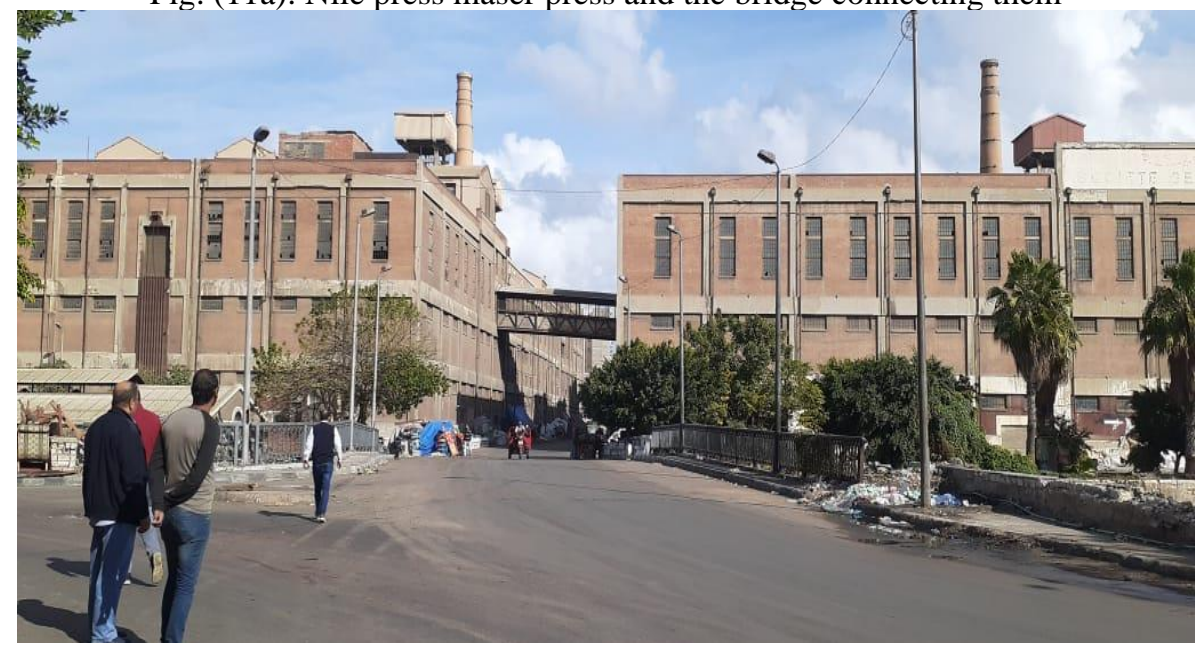

Source: The researchers

Fig. (11b): Entrance of Nile press.

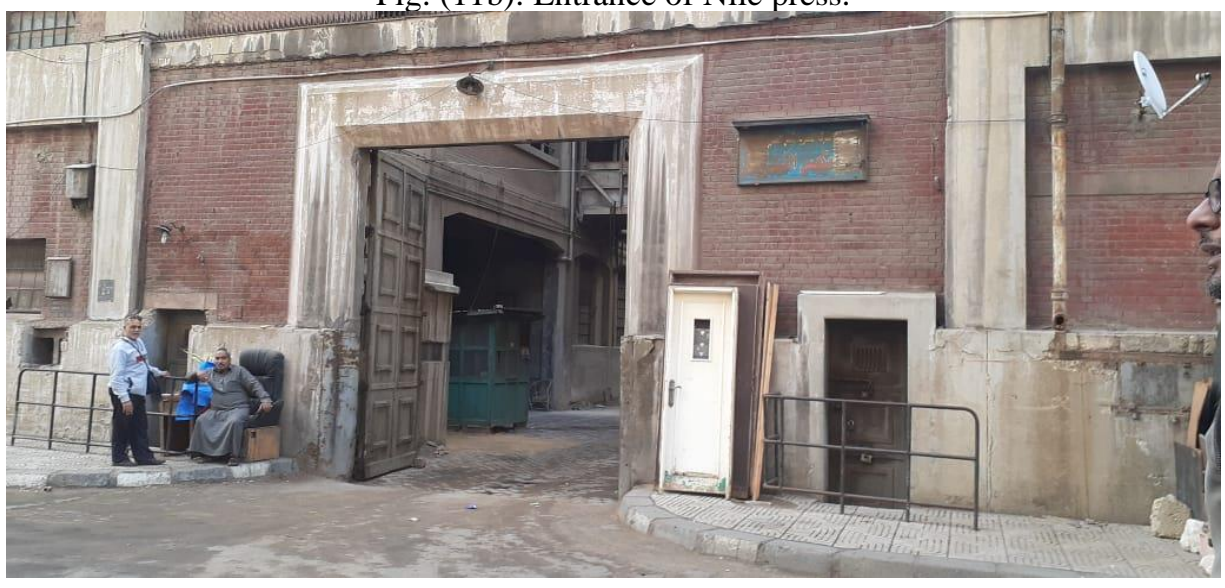

Source: The researchers 
Fig. (11c): Horizontal projection for the ground floor of Nile press

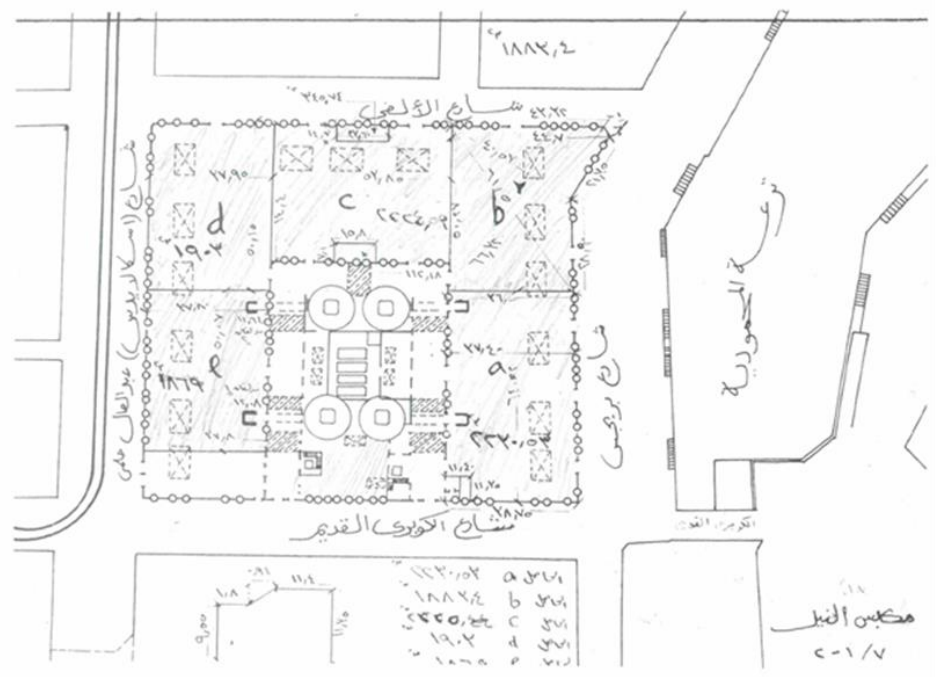

Source: Egyptian company for cotton pressing Fig. (12 a) Entrance of Masr press

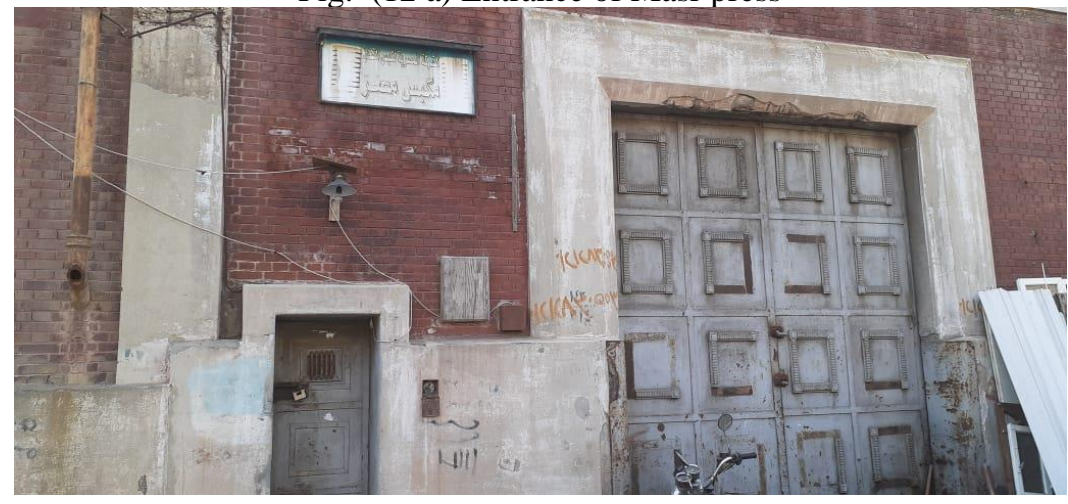

Source: The researchers

Fig. (12b): Horizontal projection for the ground floor of masr press.

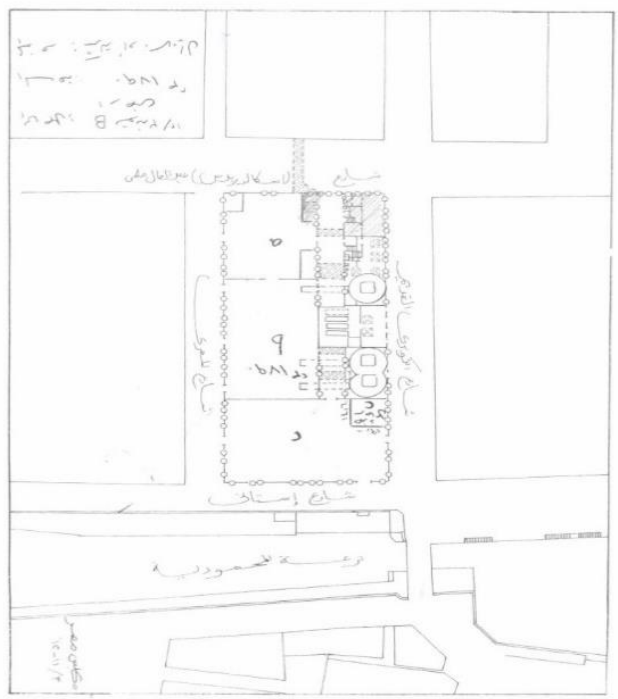

Source: Egyptian company for cotton pressing Fig. (13a): Façade of Mina EL-Basal cotton bourse. 
International Journal of Heritage, Tourism and Hospitality Vol. (14), No. (3) Spsecial Issue

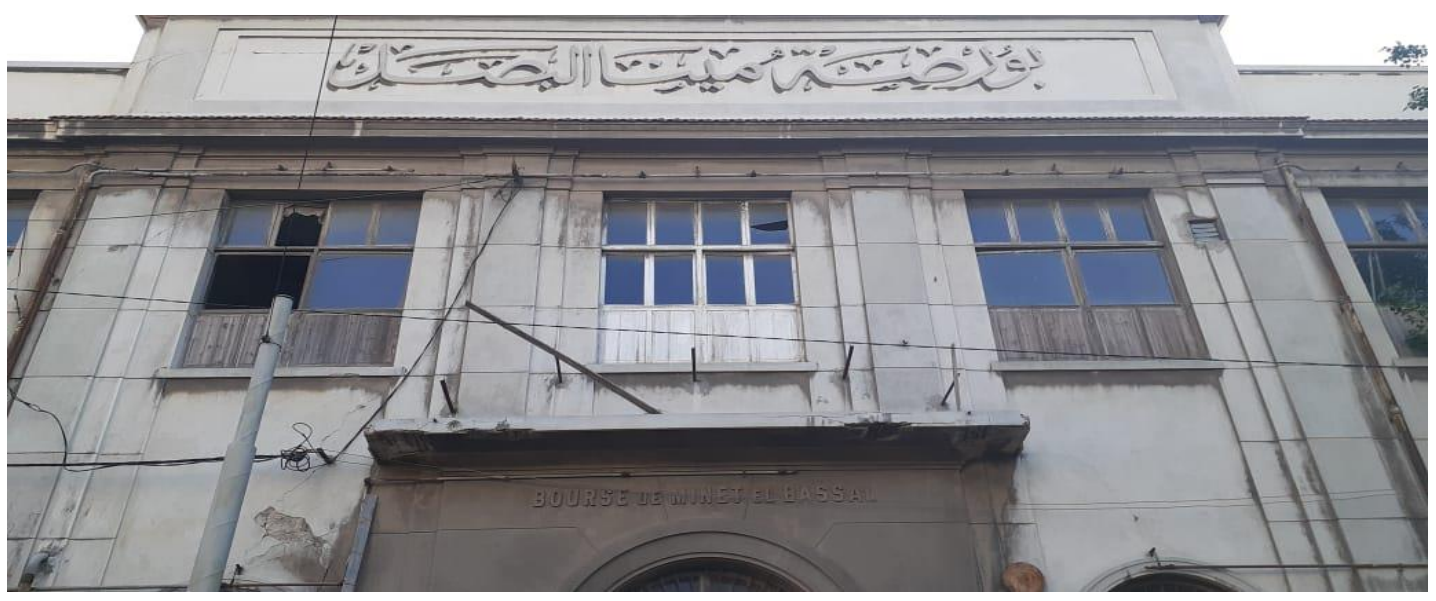

Source: The researchers

Fig. (13b): Background of Mina EL-Basal cotton bourse.

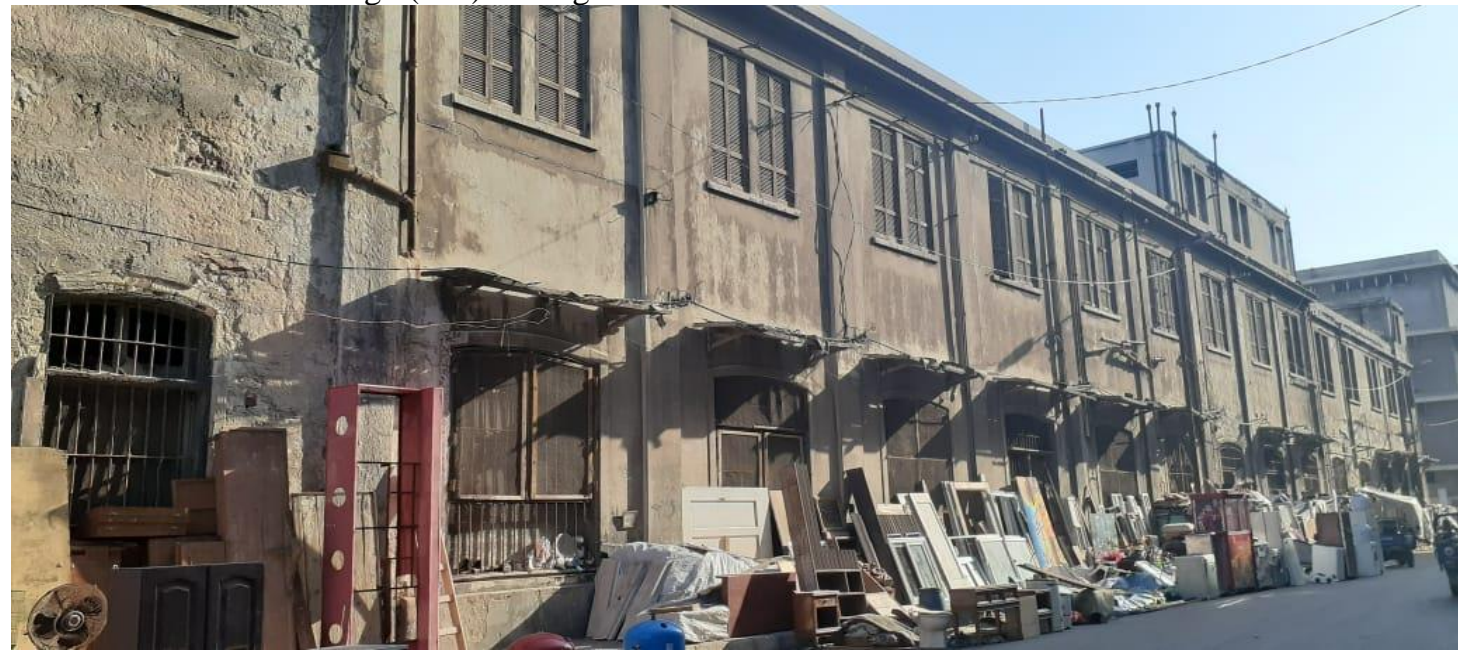

Source: The researchers

Fig. (13c): Form of conservation building of Mina EL-Basal cotton bourse.

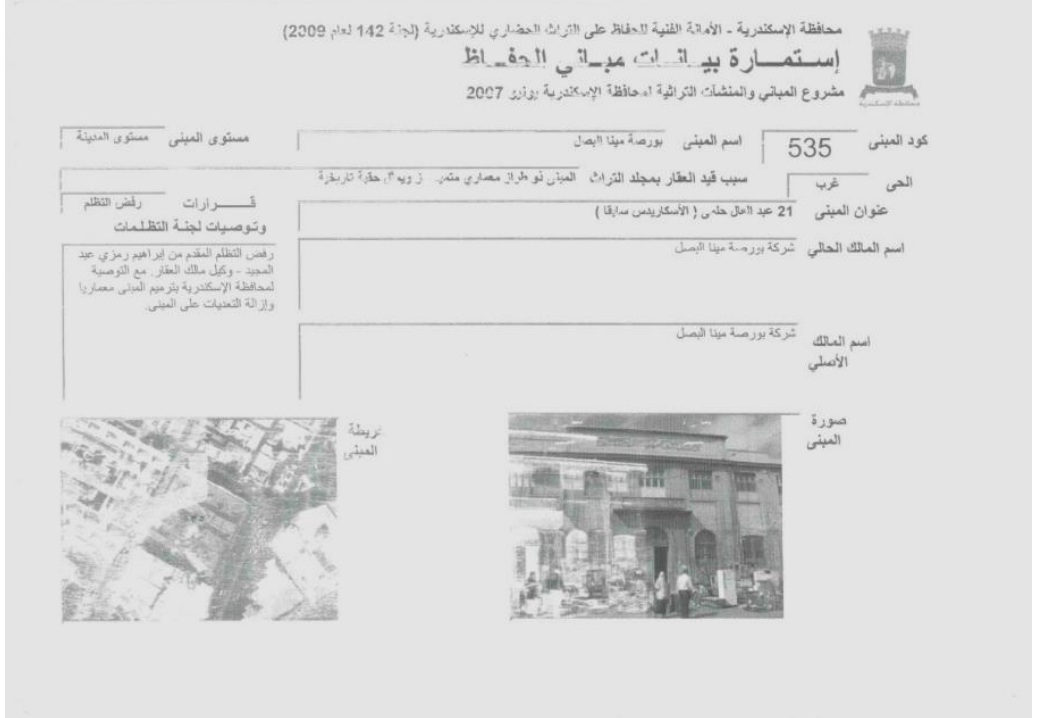

Source: National Organization for Urban Harmony(NOUH) 
Fig. (14): Plan for Alexandria for 2032 horizon.

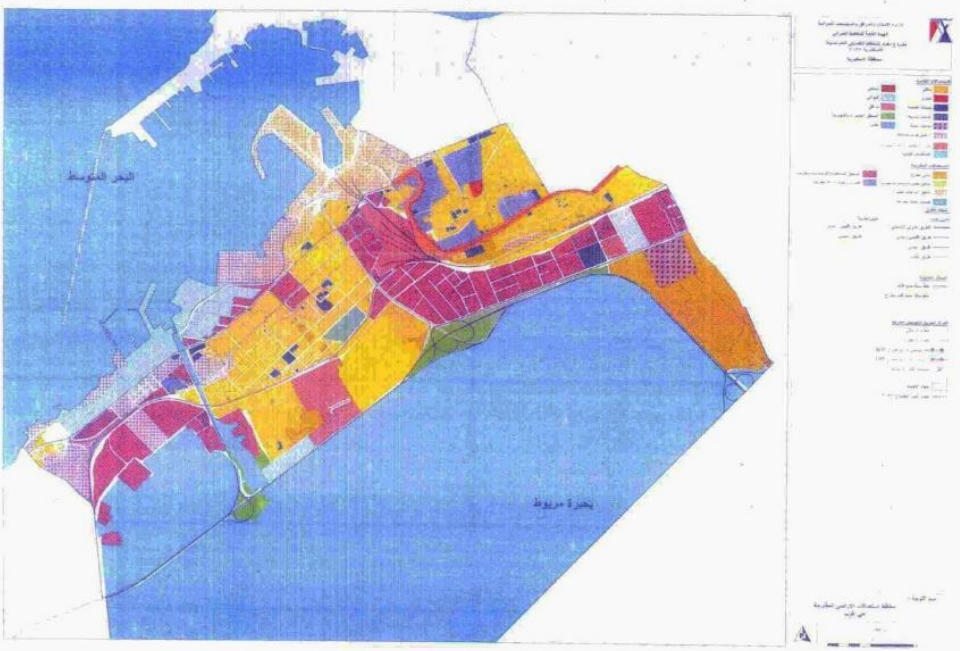

Source: West district of Alexandria.

Fig. (15):Two pictures of Al-Mahmudiya canal and renovation works
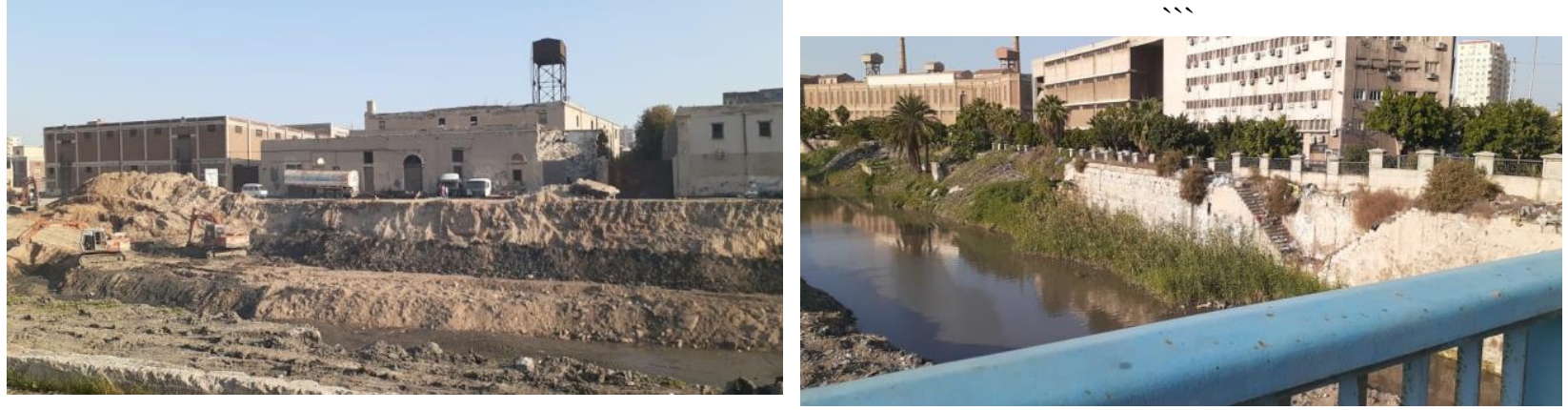

Source: researchers

Fig. (16a): Internal architecture of Nile press ground floor.

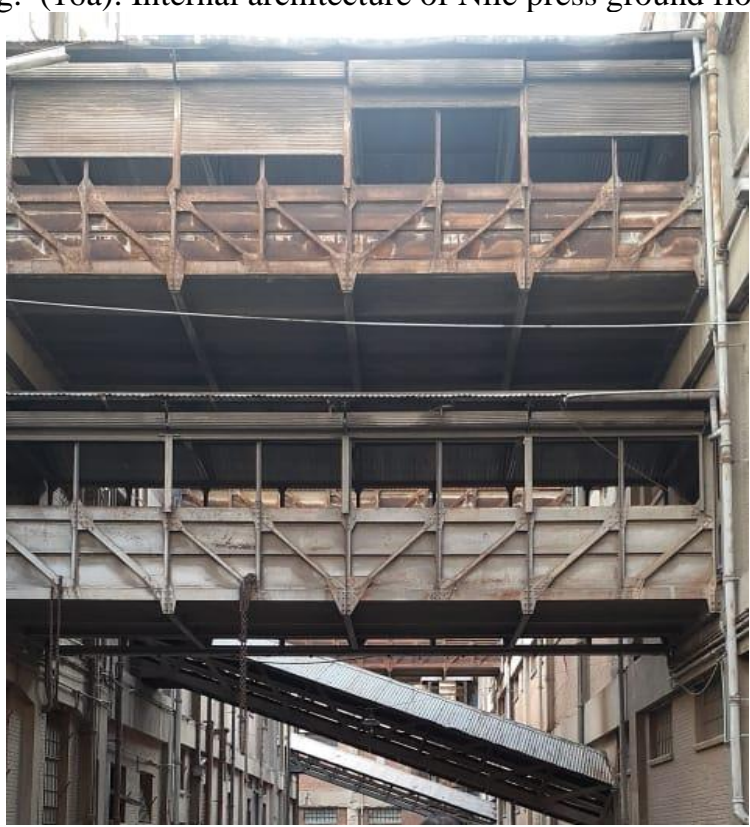

Source: The researchers 
Fig. (16b): Boilers of Nile press

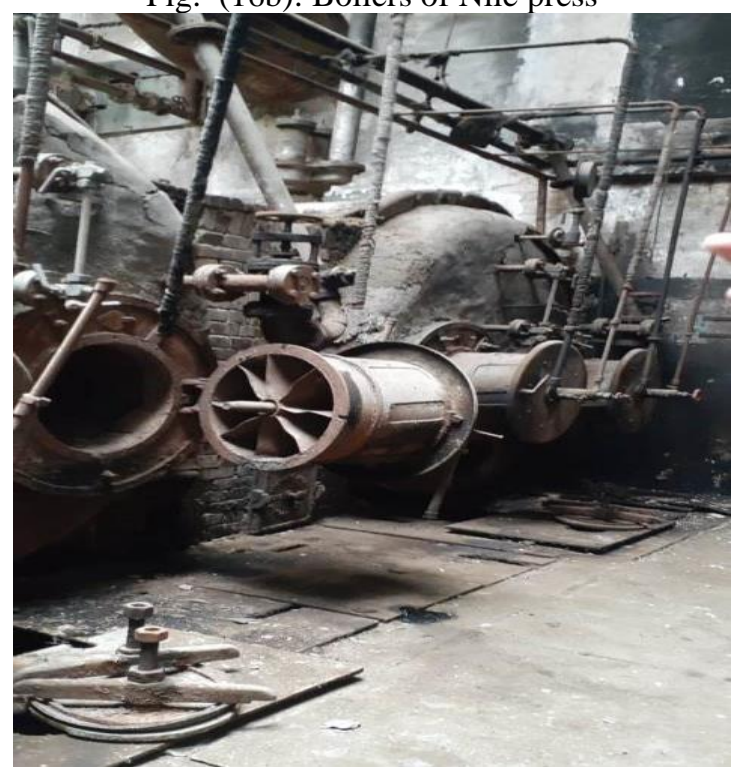

Source: The researchers

Fig. (16c): Floor of boilers of Nile press.

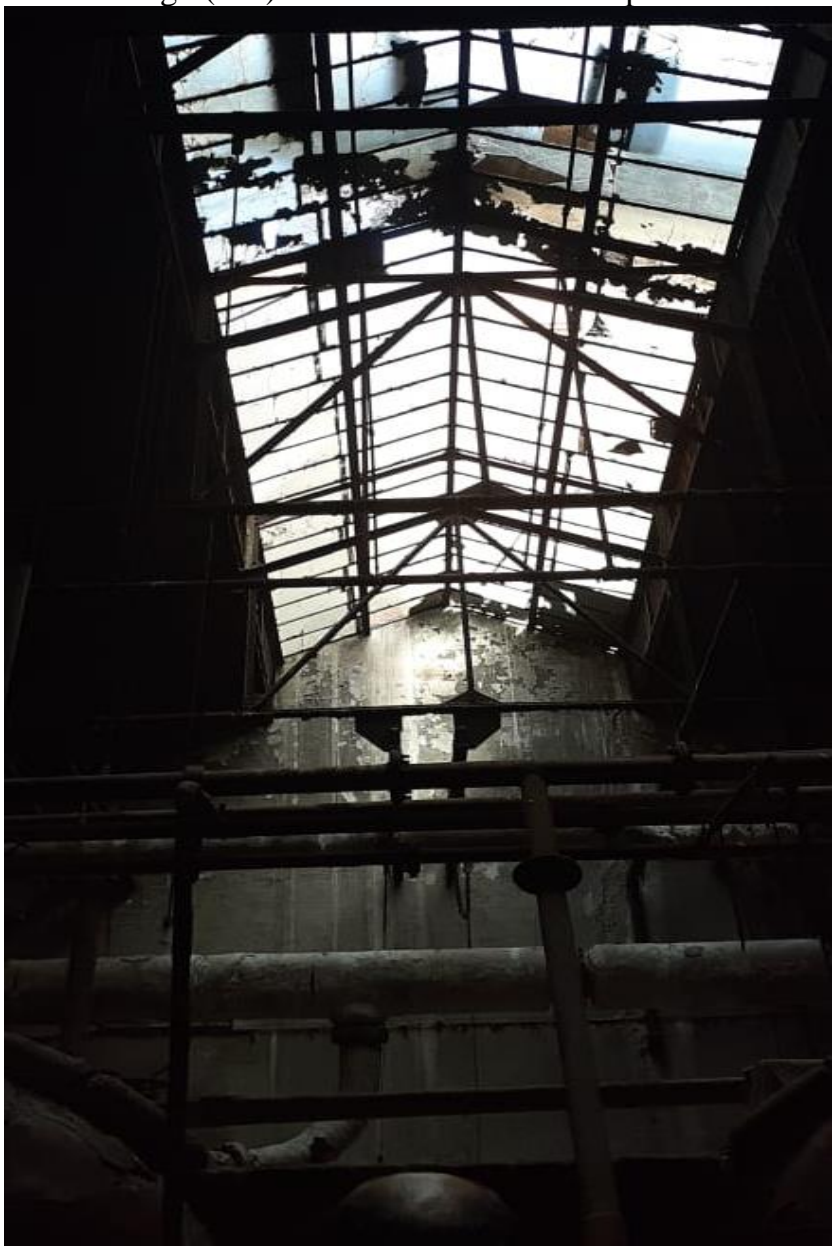

Source: The researchers

Fig. (16d): Ground floor of Nile press. 


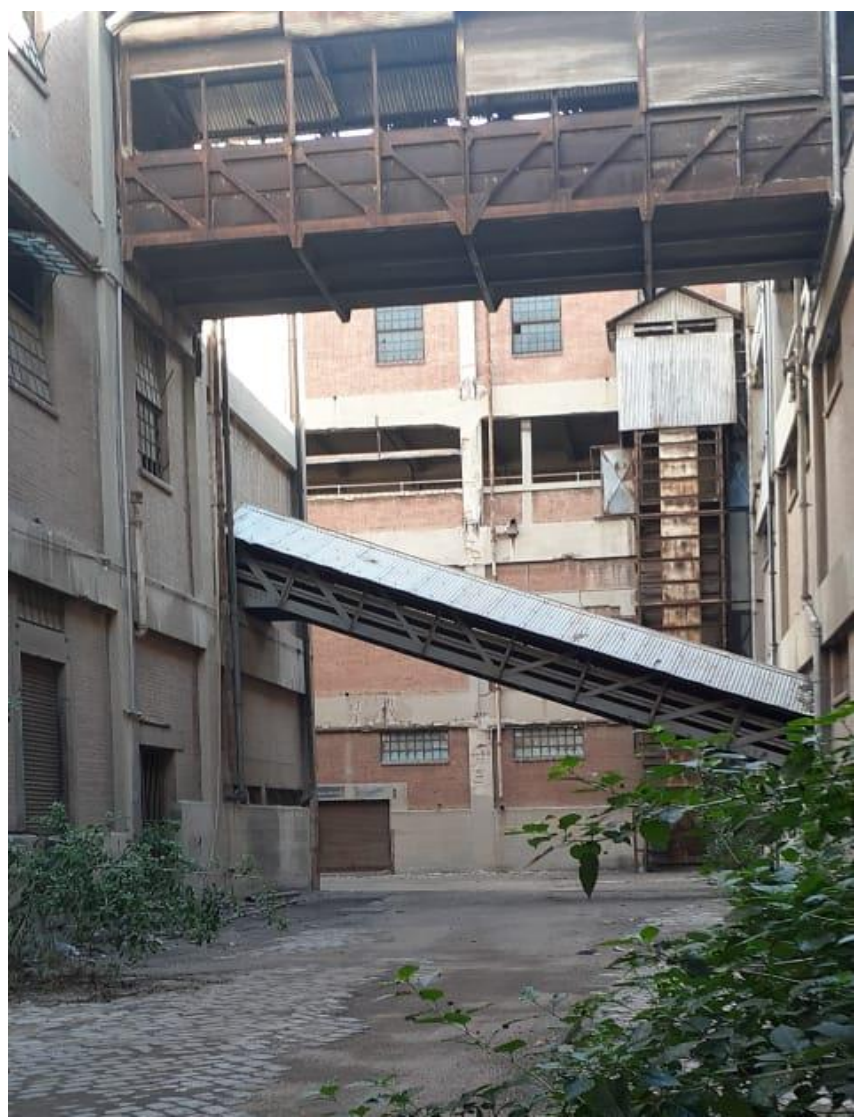

Source: The researchers

Fig. (16e): Entrance of ground floor of Nile press.

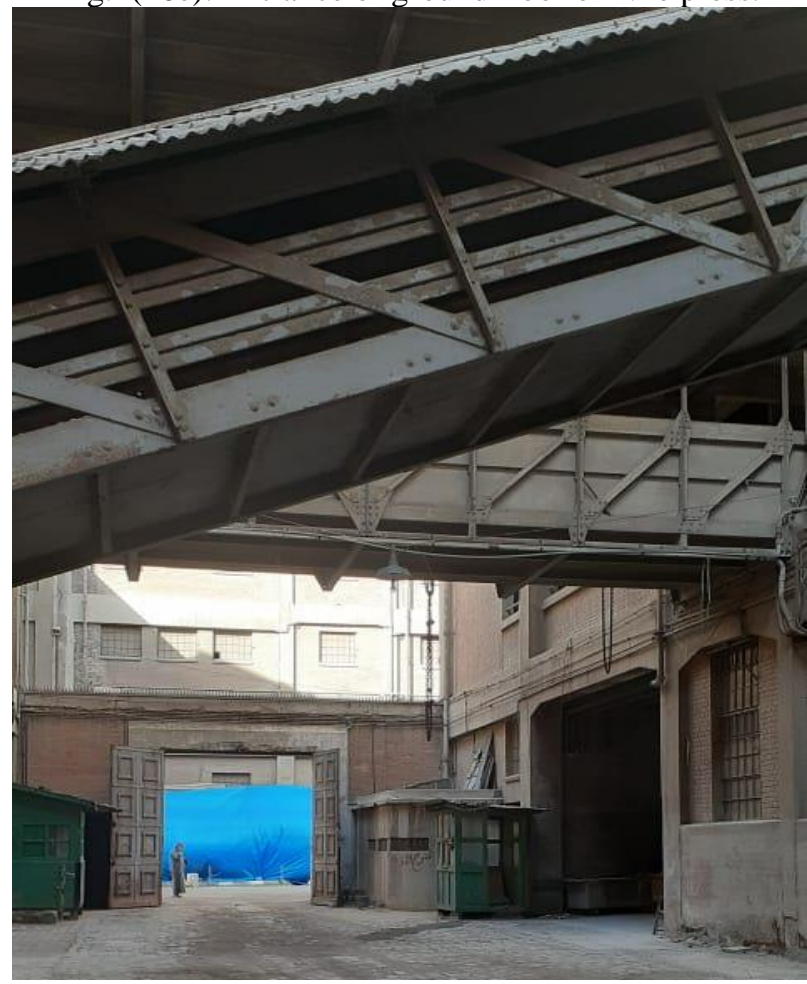

Source: The researchers

Fig. (17a): Workshop of El Tareekh press 
International Journal of Heritage, Tourism and Hospitality Vol. (14), No. (3) Spsecial Issue

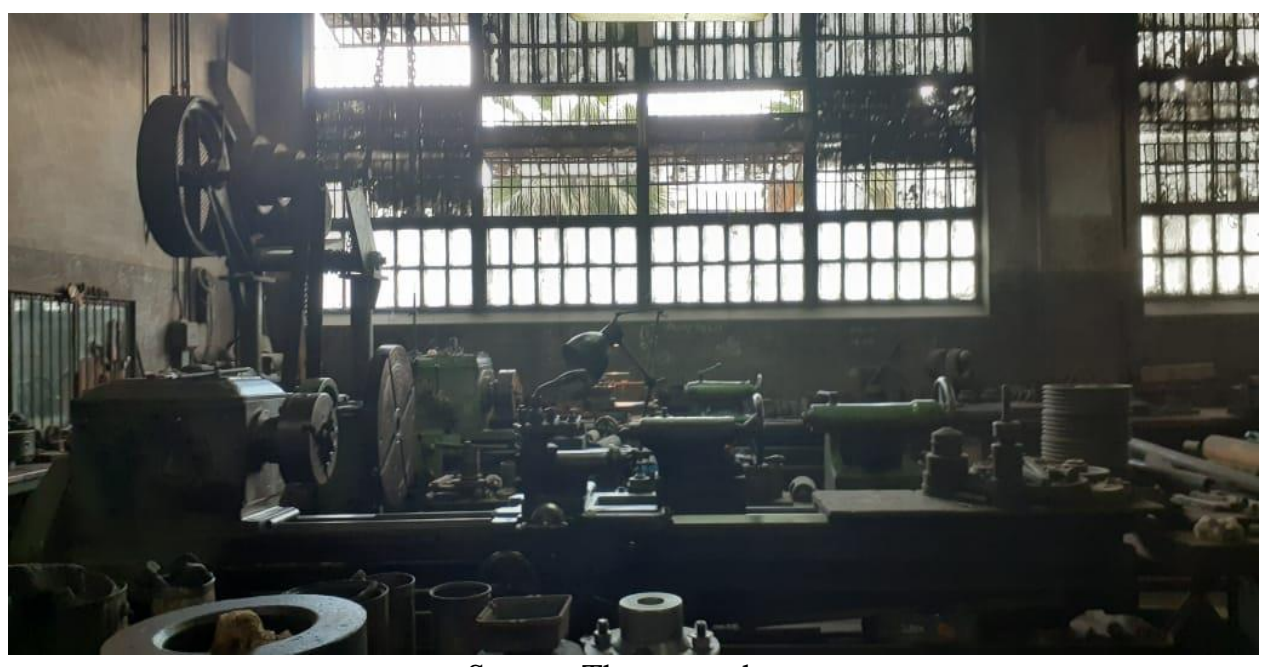

Source: The researchers

Fig. (17b): Employee office of El Tareekh press

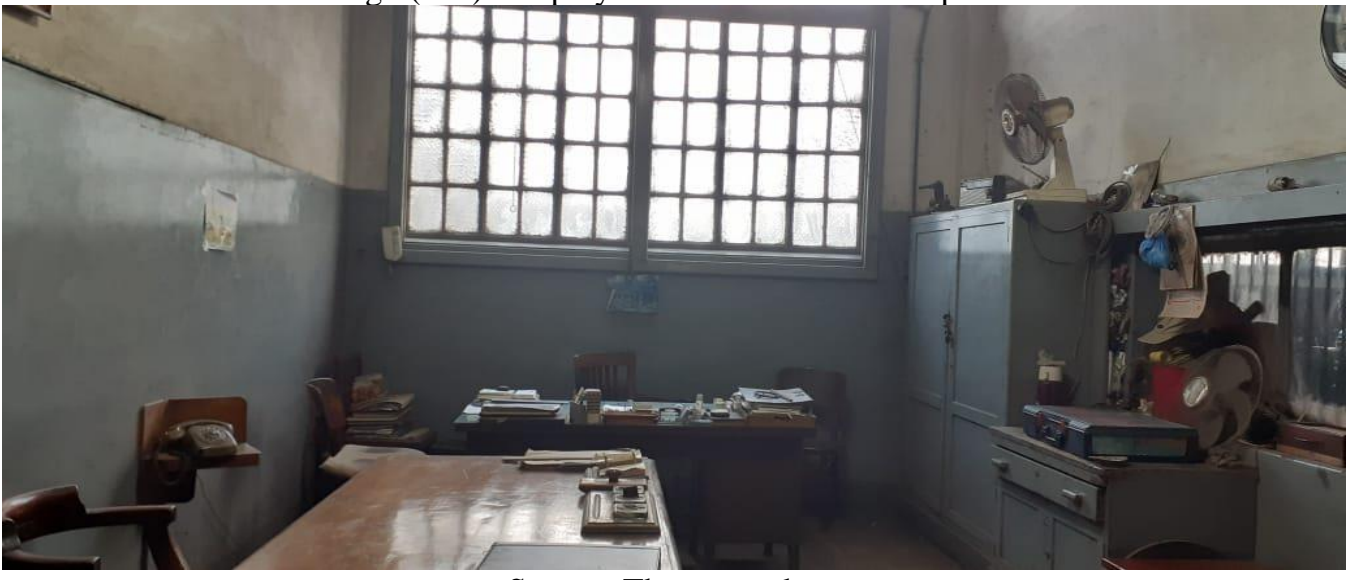

Source: The researchers

Fig. (17c): Entrance of ground floor of El Tareekh press

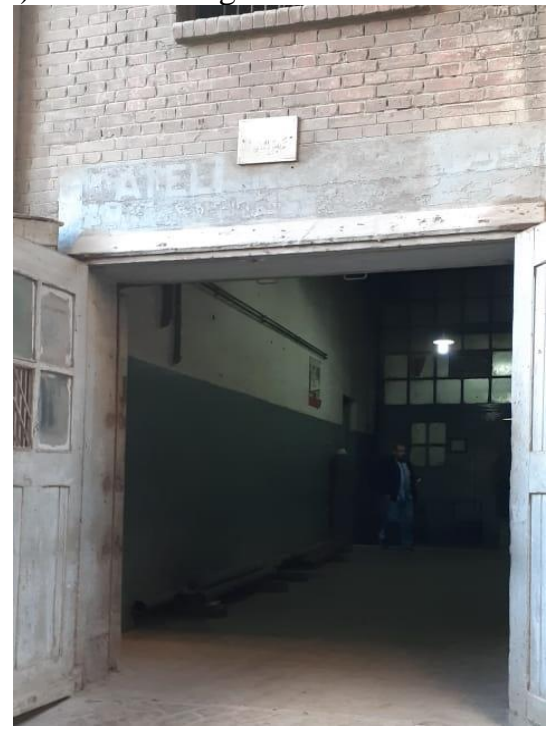

Source: The researchers

Fig. (17d): Pressing machine (1) of El Tareekh press 


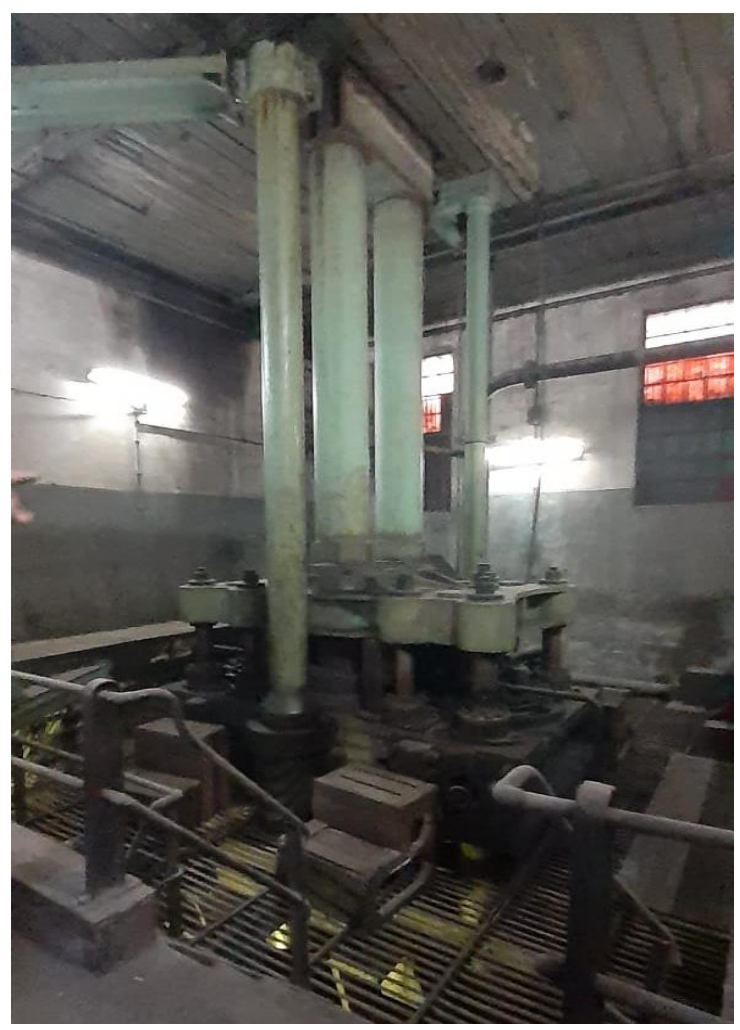

Source: The researchers

Fig. (17e): Ground floor of El Tareekh press.

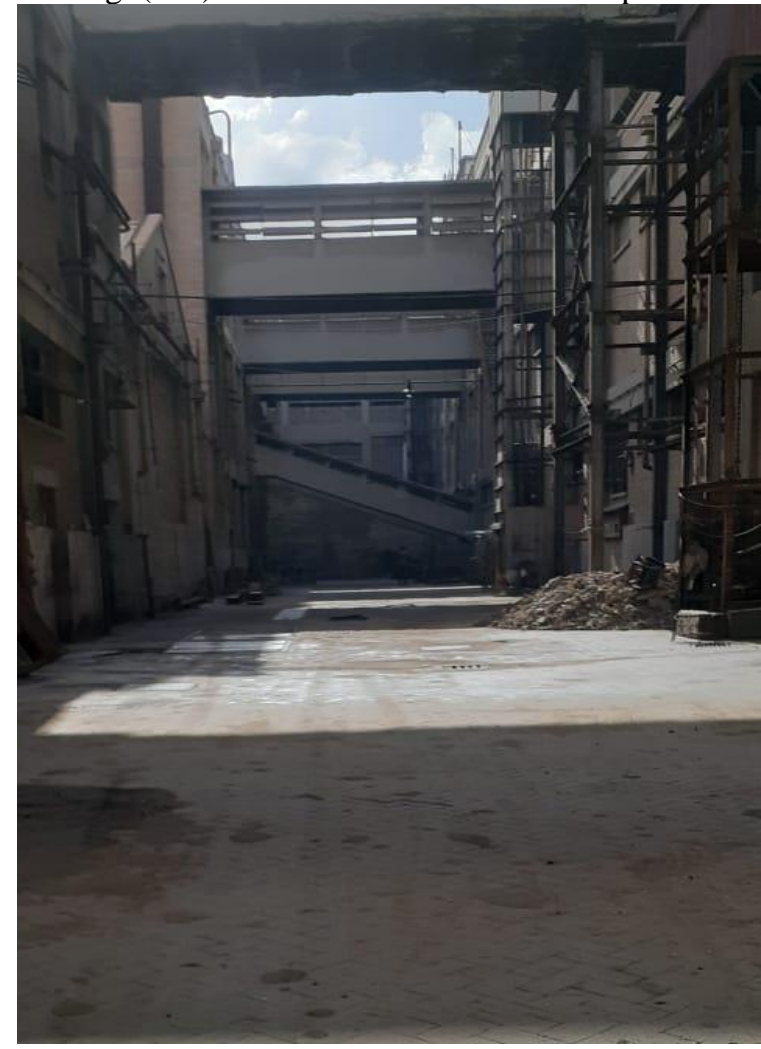

Source: The researchers

Fig (18a): Cotton bale souvenirs

Fig. (18b): Cotton pressing machines for souvenirs of 
International Journal of Heritage, Tourism and Hospitality Vol. (14), No. (3) Spsecial Issue

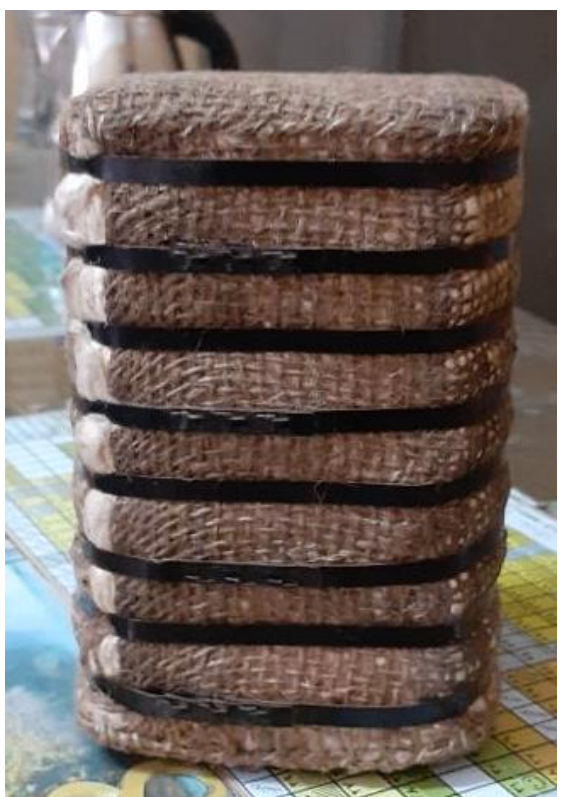

Source: The researchers cotton bales in Masr press.

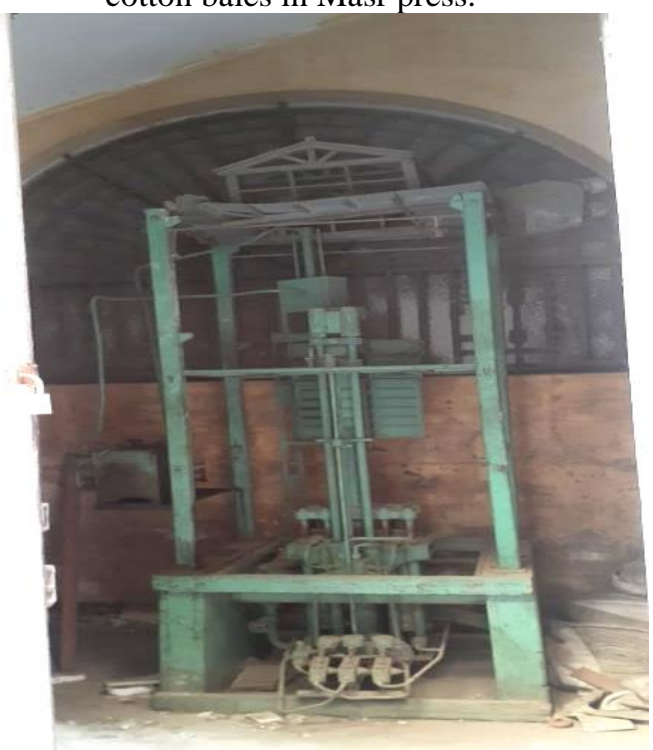

Source: The reserchers

Fig. (18c): Entrance of Masr press first floor

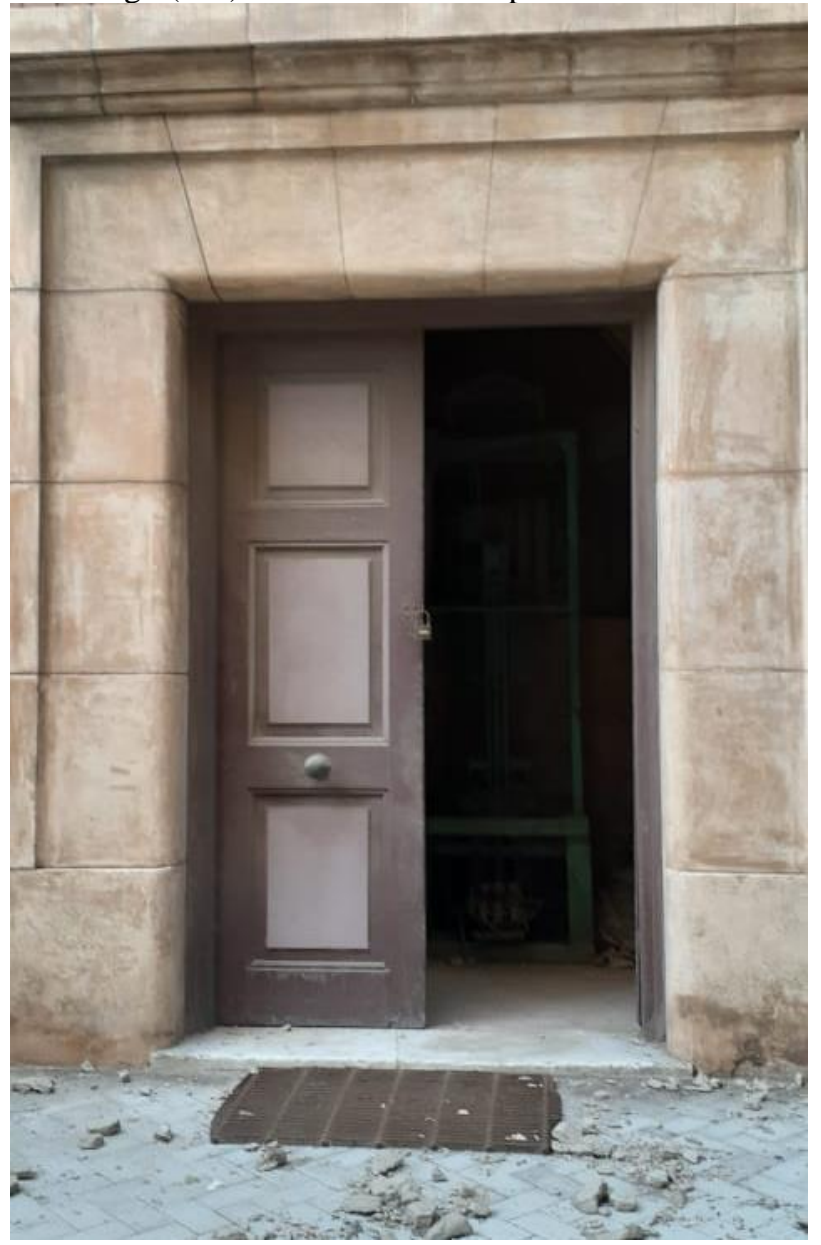

Source: The researchers

Fig. (18d): Masr press roof view 


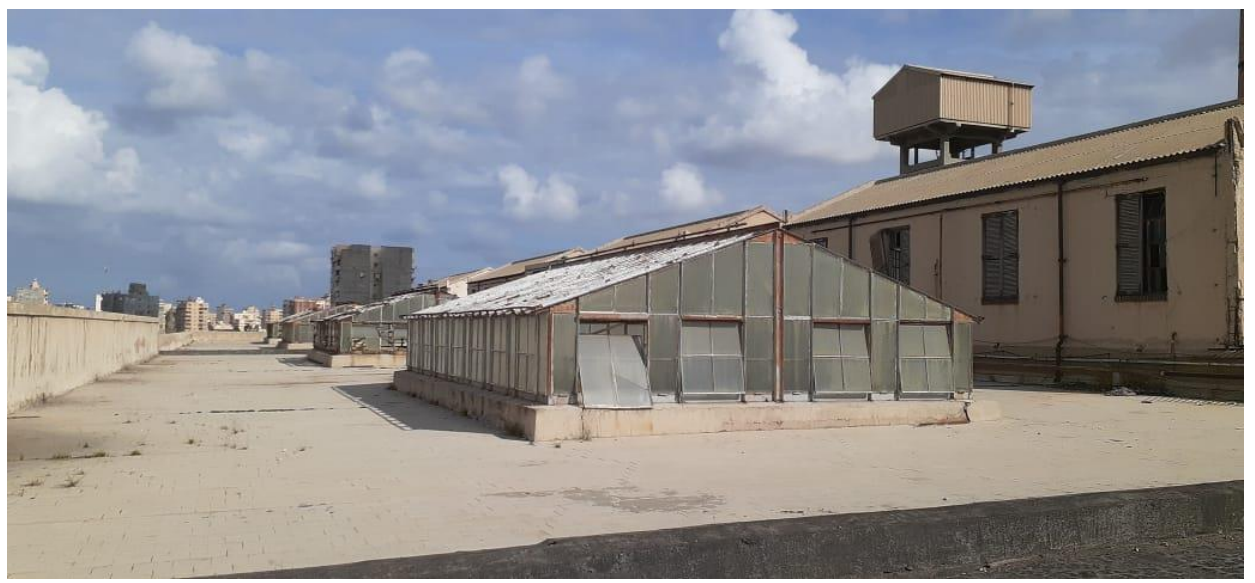

Source: The researchers

Fig. (18e): another roof view of Masr press

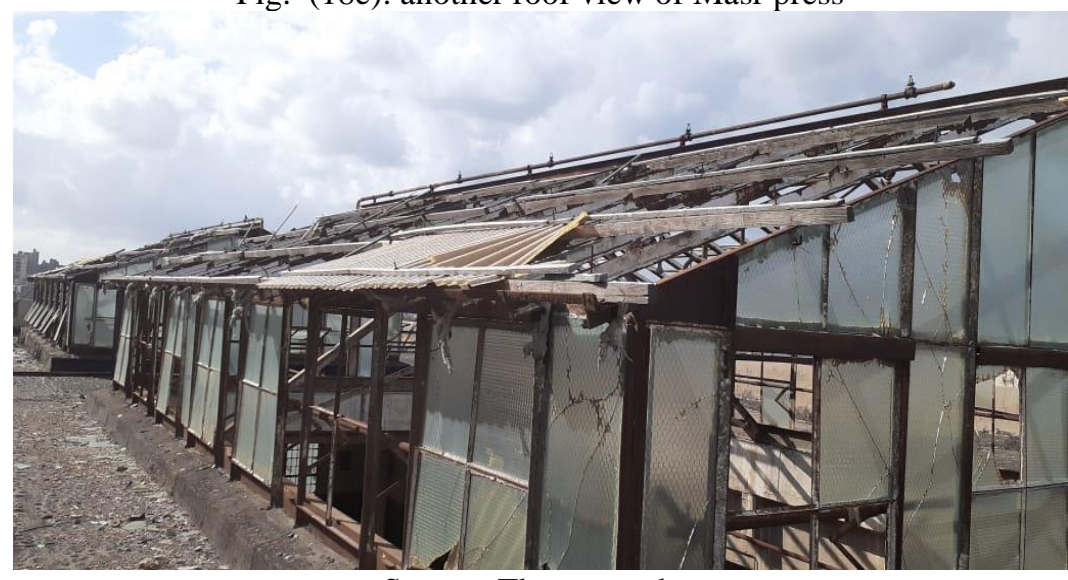

Source: The researchers

Fig. (18f): Masr press internal architecture ground floor

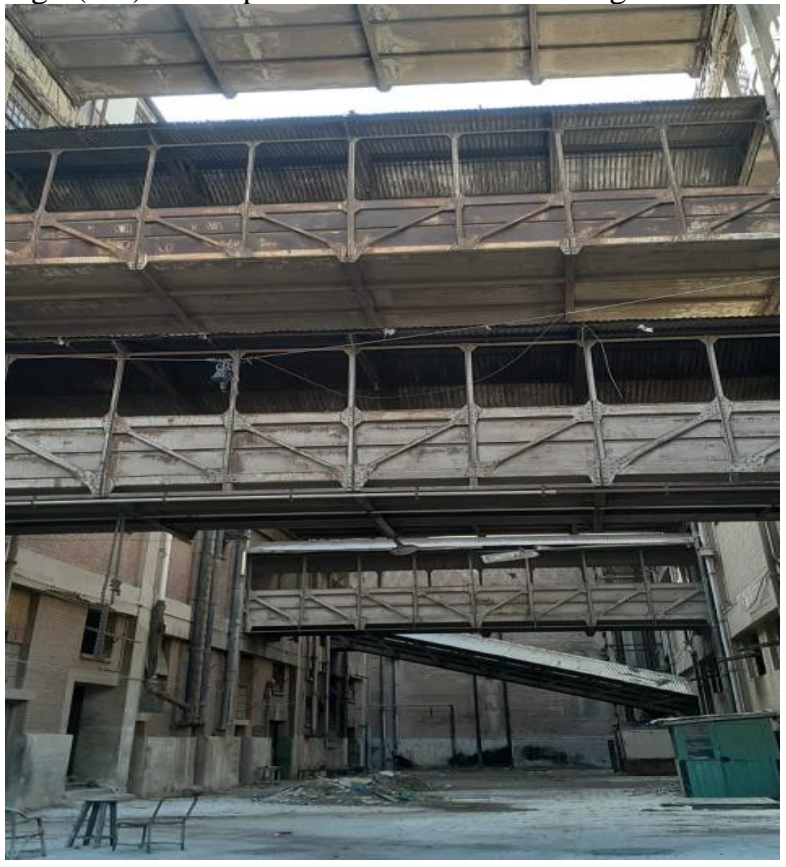

Source: The researchers

Fig. (18g) view of Masr press roof overlooking western part. 


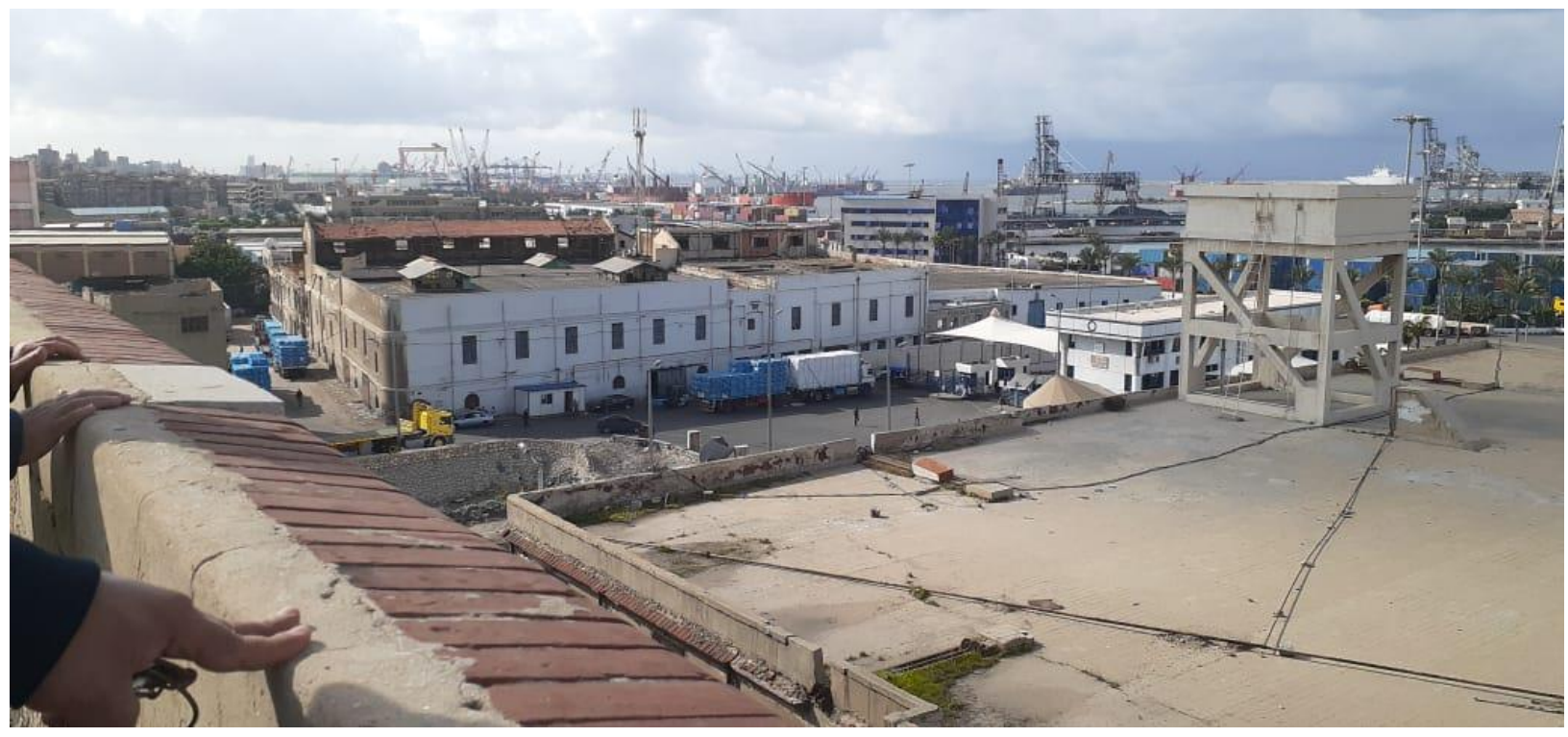

Source: The researchers

Fig. (18h): Another view of Masr press roof overlooking western part.

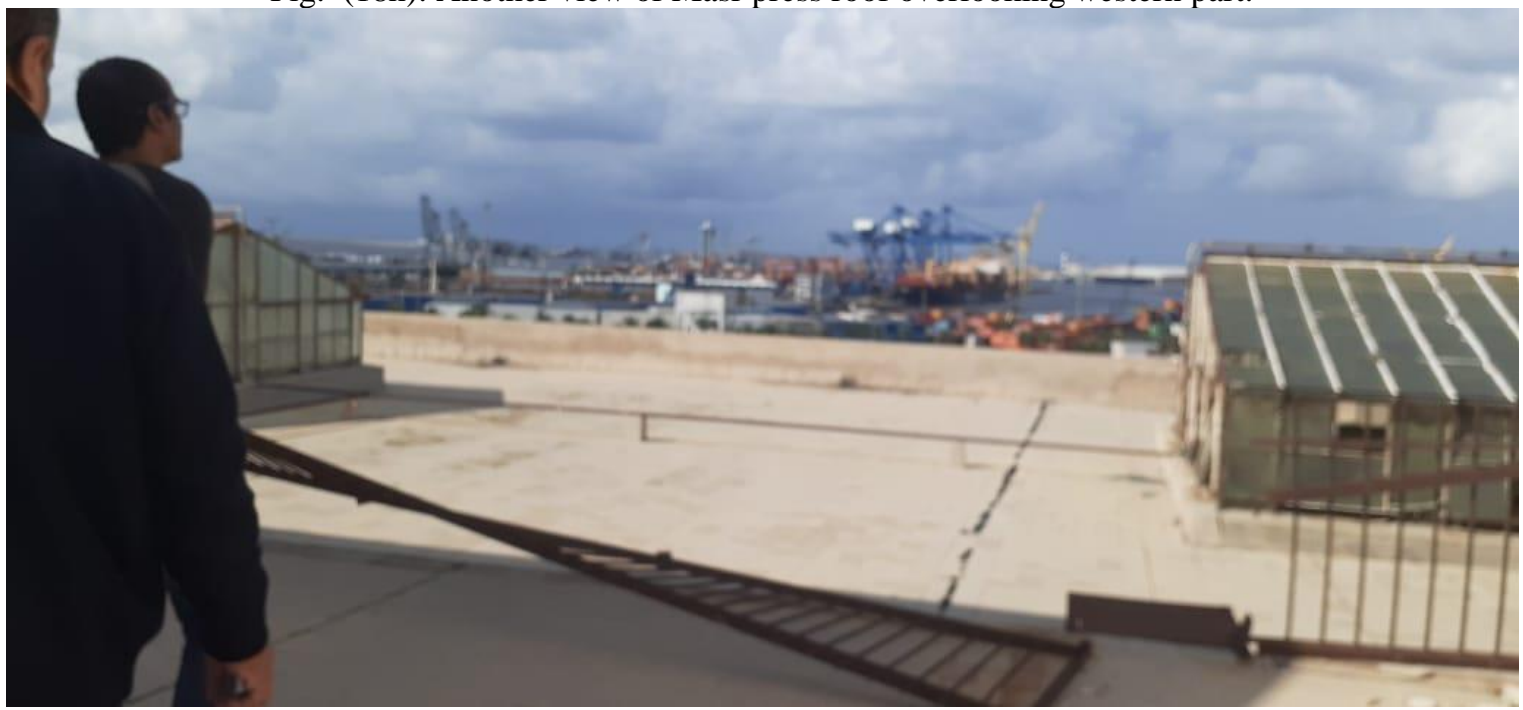

Source: The researchers

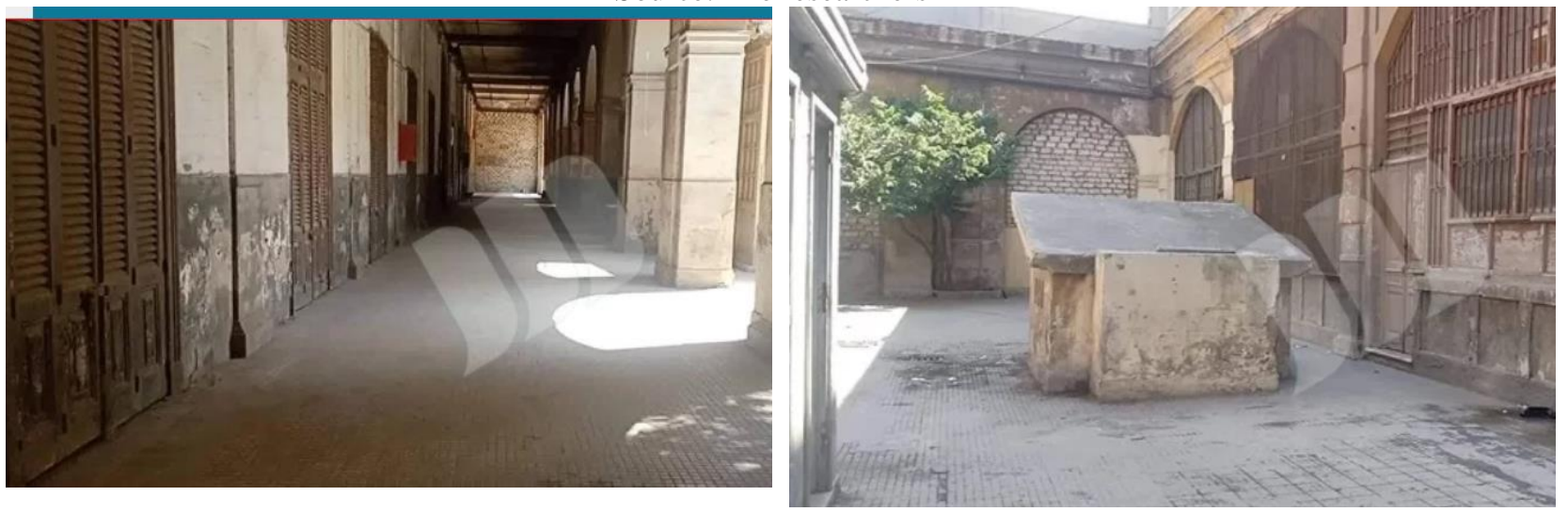


International Journal of Heritage, Tourism and Hospitality Vol. (14), No. (3) Spsecial Issue
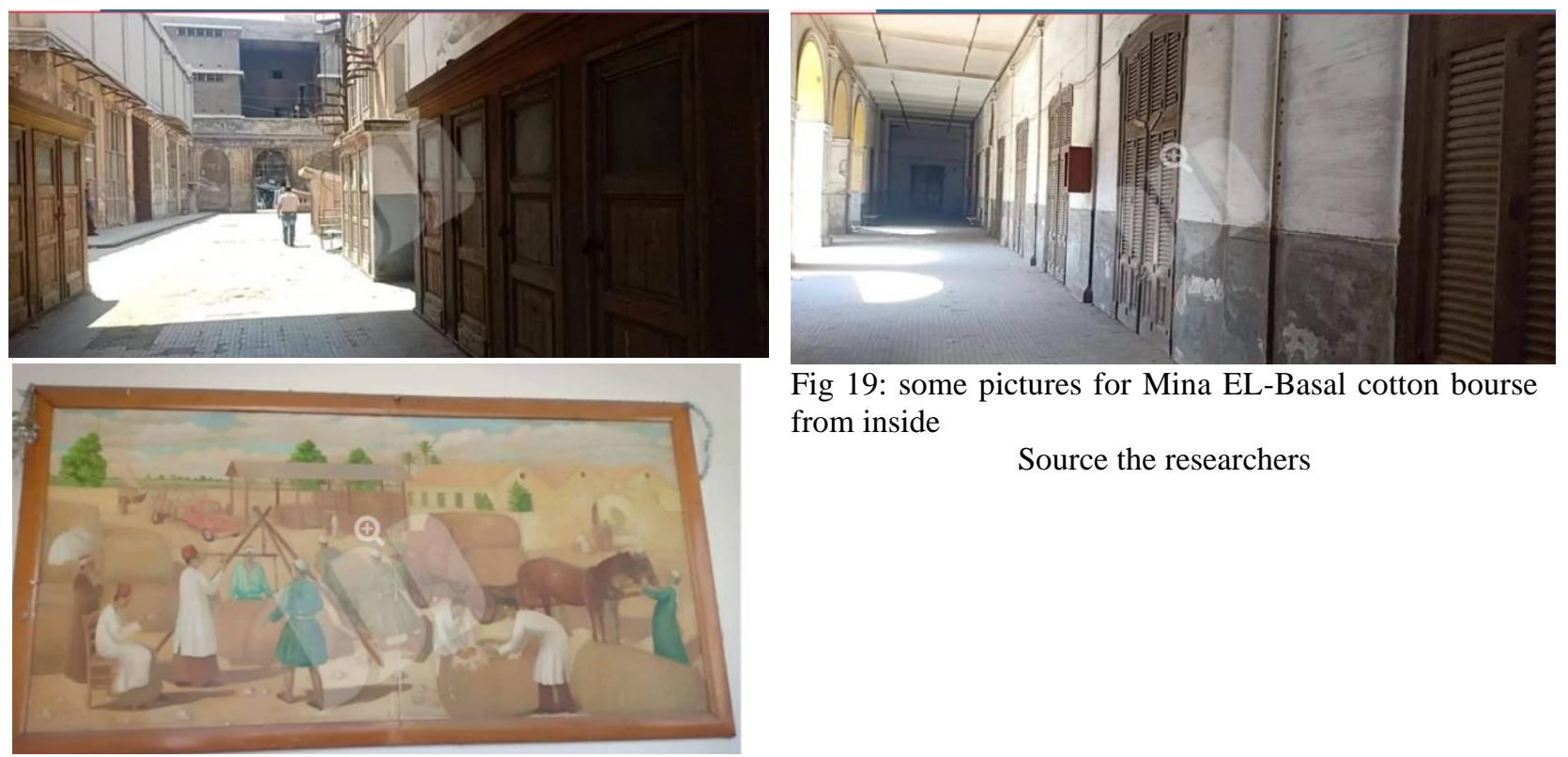

Fig 19: some pictures for Mina EL-Basal cotton bourse from inside

Source the researchers 